\title{
Salinity stress alleviation using arbuscular mycorrhizal fungi. A review
}

\author{
Rosa Porcel • Ricardo Aroca • \\ Juan Manuel Ruiz-Lozano
}

Accepted: 2 November 2010 / Published online: 15 March 2011

(C) INRA and Springer Science+Business Media B.V. 2011

\begin{abstract}
Salinity is one of the most severe environmental stress as it decreases crop production of more than $20 \%$ of irrigated land worldwide. Hence, it is important to develop salt-tolerant crops. Understanding the mechanisms that enable plant growth under saline conditions is therefore required. Acclimation of plants to salinized conditions depends upon activation of cascades of molecular networks involved in stress sensing, signal transduction, and the expression of specific stress-related genes and metabolites. The stress signal is first perceived at the membrane level by the receptors and then transduced in the cell to switch on the stress-responsive genes which mediate stress tolerance. In addition to stress-adaptative mechanisms developed by plants, arbuscular mycorrhizal fungi have been shown to improve plant tolerance to abiotic environmental factors such as salinity. In this review, we emphasize the significance of arbuscular mycorrhizal fungi alleviation of salt stress and their beneficial effects on plant growth and productivity. Although salinity can affect negatively arbuscular mycorrhizal fungi, many reports show improved growth and performance of mycorrhizal plants under salt stress conditions. These positive effects are explained by improved host plant nutrition, higher $\mathrm{K}^{+} / \mathrm{Na}^{+}$ratios in plant tissues and a better osmotic adjustment by accumulation of compatible solutes such as proline, glycine betaine, or soluble sugars. Arbuscular mycorrhizal plants also improve photosynthetic- and water use efficiency under salt stress. Arbuscular mycorrhizal plants enhance the activity of antioxidant enzymes in order to cope with the reactive
\end{abstract}

R. Porcel $(\triangle) \cdot$ R. Aroca $\cdot$ J. M. Ruiz-Lozano

Departamento de Microbiología del Suelo y Sistemas Simbióticos,

Estación Experimental del Zaidín (CSIC). Prof. Albareda, 1,

18008 Granada, Spain

e-mail: rporcel@eez.csic.es oxygen species generated by salinity. At the molecular level, arbuscular mycorrhizal symbiosis regulates the expression of plant genes involved in the biosynthesis of proline, of genes encoding aquaporins, and of genes encoding late embryogenesis abundant proteins, with chaperone activity. The regulation of these genes allows mycorrhizal plants to maintain a better water status in their tissues. Gene expression patterns suggest that mycorrhizal plants are less strained by salt stress than non-mycorrhizal plants. In contrast, scarce information is available on the possible regulation by the arbuscular mycorrhizal symbiosis of plant genes encoding $\mathrm{Na}^{+} / \mathrm{H}^{+}$antiporters or cyclic nucleotide-gated channels. These genes encode proteins with a key role in the regulation of uptake, distribution and compartimentation of sodium and other ions within the plant, and are major determinants for the salt sensitiveness of a plant. Thus, we propose that investigating the participation of cation proton antiporters and cyclic nucleotide-gated channels on arbuscular mycorrhizal symbiosis under salinity is a promising field that should shed further light on new mechanisms involved in the enhanced tolerance of mycorrhizal plants to salt stress.

Keywords Abiotic stress - Aquaporin - Antioxidant . Arbuscular mycorrhizal fungi $\cdot$ Cation antiporter.

Homeostasis $\cdot$ Salinity $\cdot$ Stress tolerance
Abbreviations
ABA Abscisic acid
AMF Arbuscular mycorrhizal fungus
BAS Branched-absorbing structure
CNGC Cyclic nucleotide-gated channel
Lo Root hydraulic conductivity
NMP Nucleotide monophosphate
NIP Nodulin 26-like intrinsic protein 


$\begin{array}{ll}\text { PIP } & \text { Plasma membrane intrinsic protein } \\ \text { P5CS } & \Delta^{1} \text {-pyrroline-5-carboxylate-synthetase } \\ \text { ROS } & \text { Reactive oxygen species } \\ \text { RWC } & \text { Relative water content } \\ \text { TIP } & \text { Tonoplast intrinsic protein } \\ \text { SIP } & \text { Small and basic intrinsic protein } \\ \text { Tleaf } & \text { Leaf water potential }\end{array}$

Contents

1. Introduction. . . . . . . . . . . . . . . 1

2. Morphological features and development of arbuscular mycorrhizal symbiosis. . . . . . . . . . . . . . 3

3. Ecological significance of arbuscular mycorrhizal symbiosis. . . . . . . . . . . . . . . . . . .4

4. Salinity effects on plants. . . . . . . . . . . . . .5

5. Salinity effects on arbuscular mycorrhizal fungi. .... .6

6. Arbuscular mycorrhizal effects on plant biomass and nutrient uptake. . . . . . . . . . . . .

7. Biochemical changes. . . . . . . . . . . .8

7.1. Proline and other osmolytes. . . . . . . . . . .8

7.2. ABA content. . . . . . . . . . . . . . . . . .9

7.3. Antioxidant system. . . . . . . . . . . . . . . . .9

8. Physiological changes. . . . . . . . . . . . . 10

9. Molecular changes. . . . . . . . . . . . . . . . . 11

9.1. P5CS. . . . . . . . . . . . . .11

9.2. Aquaporins. ....................11

9.3. Late embryogenesis abundant proteins. . . . . . .12

9.4. Cation channels and transporters. . . . . . . . 13

9.4.1. $\mathrm{Na}^{+} / \mathrm{H}^{+}$antiporters. . . . . . . . . . . 13

9.4.2. Cyclic nucleotide-gated channels. . . . . .14

10. Perspectives for future studies. . . . . . . . . . 15

11. References ................... 16

\section{Introduction}

Salinization of soil is a serious land degradation problem and is increasing steadily in many parts of the world, in particular in arid and semiarid areas (Giri et al. 2003; AlKaraki 2006). Increased salinization of arable land is expected to have devastating global effects, resulting in $30 \%$ land loss within the next 25 years and up to $50 \%$ by the middle of twenty-first century (Wang et al. 2003). High soil salinity causes both hyperionic and hyperosmotic stress and can lead to plant demise. Salinity in a given land area depends upon various factors like amount of evaporation (leading to increase in salt concentration), or the amount of precipitation (leading to decrease in salt concentration) (Mahajan and Tuteja 2005). High salt concentration $\left(\mathrm{Na}^{+}\right)$in particular which deposit in the soil can alter the basic texture of the soil resulting in decreased soil porosity and consequently reduced soil aeration and water conductance. High salt depositions in the soil generate a low water potential zone in the soil, making it increasingly difficult for the plant to acquire both water as well as nutrients. The basic physiology of high salt stress and drought stress overlaps with each other. Therefore, salt stress essentially results in a water-deficit condition in the plant and takes the form of a physiological drought (Mahajan and Tuteja 2005). In plants, both drought and salinization are manifested primarily as osmotic stress, resulting in the disruption of homeostasis and ion distribution in the cell (Serrano et al. 1999; Zhu 2001). Plants differ greatly in their tolerance to salinity, as reflected in their different growth responses (Fig. 1). Salt sensitive plants, also known as glycophytes include rice (Oryza sativa), maize (Zea mays), soybean (Glycine max) or beans (Phaseolus vulgaris), while some halophytes plants are saltbush (Atriplex amnicola), alfalfa (Medicago sativa), or pepercress (Lepidium $s p$.).

Plants, in their natural environment are colonized both by external and internal microorganisms. Arbuscular mycorrhizal fungi (AMF) are ubiquitous among a wide array of soil microorganisms inhabiting the rhizosphere. These fungi constitute an important integral component of the natural ecosystem and are known to exist in saline environments (Giri et al. 2003). The proportion of vascular plant species forming AM is commonly overestimated (Trappe 1987), probably as a result of the low proportion of species and environments surveyed (Brundett and Abbott 1991). Although AMF exist in saline soils, the growth and colonization of plants may be affected by the excess of salinity, which can inhibit the growth of microbes due to osmotic and/or toxic effects of salts (Juniper and Abbott 2006). AM symbiosis has been demonstrated to increase resistance to soil salinity in a variety of host plants such as maize, clover, tomato, cucumber, and lettuce (Rosendahl and Rosendahl 1991; Ruiz-Lozano and Azcón 1996; Al-Karaki et al. 2001; Feng et al. 2002).

Although it is clear that AM fungi mitigate growth reduction caused by salinity, the mechanism involved remains unresolved. So far, studies on salt stress tolerance in mycorrhizal plants have suggested that AM plants grow better due to improved mineral nutrition and physiological processes like photosynthesis or water use efficiency, the production of osmoregulators, higher $\mathrm{K}^{+} / \mathrm{Na}^{+}$ratios and compartmentalization of sodium within some plant tissues (Ruiz-Lozano et al. 1996; Giri et al. 2003; Al-Karaki 2006). In this review, we present a comprehensive analysis of nutritional, biochemical, physiological, and molecular changes that occur in plants when colonized by AM and subjected to salt stress. 
Fig. 1 Diversity in the salt tolerance of various cultivated and non-cultivated species. In the figure, species growing at less than $300 \mathrm{mM} \mathrm{NaCl}$ are considered glycophytes while those growing over $300 \mathrm{mM}$ $\mathrm{NaCl}$ are considered halophytes. Pictures represent a arabidopsis (Arabidopsis thaliana), b rice (Oryza sativa), c saltbush (Atriplex amnicola), d alfalfa (Medicago sativa), e prickly saltwort (Salsola kali), f barrier saltbush (Enchylaena tomentosa), $\mathbf{g}$ fringed redmaid (Calandrinia ciliata), h pepercress (Lepidium sp.)

\section{Salt tolerance}

\begin{tabular}{ll}
\hline \hline \multicolumn{1}{c}{$\begin{array}{c}\text { Salt sensitive plants } \\
\text { Glycophytes }\end{array}$} & $\begin{array}{l}\text { Salt sensitive plants } \\
\text { Halophytes }\end{array}$ \\
\hline \multicolumn{1}{c}{$<00 \mathrm{mM} \mathrm{NaCl}$} & $>300 \mathrm{mM} \mathrm{NaCl}$ \\
Arabidopsis (Arabidopsis thaliana) & Saltbush (Atriplex amnicola) \\
$\begin{array}{l}\text { Rice (Orva sativa) } \\
\text { Durum wheat (Triticum turgidum ssp durum) } \\
\text { Bread wheat (Triticum aestivum) }\end{array}$ & $\begin{array}{l}\text { Tall wheatgrass (Thinopyrum ponticum) } \\
\text { Alfalfa (Medicago sativa) }\end{array}$ \\
Barley (Hordeum vulgare) & $\begin{array}{l}\text { Pepercress (Lepidium sp) } \\
\text { Barrier saltbush (Enchvlaena tomentosa) }\end{array}$
\end{tabular}
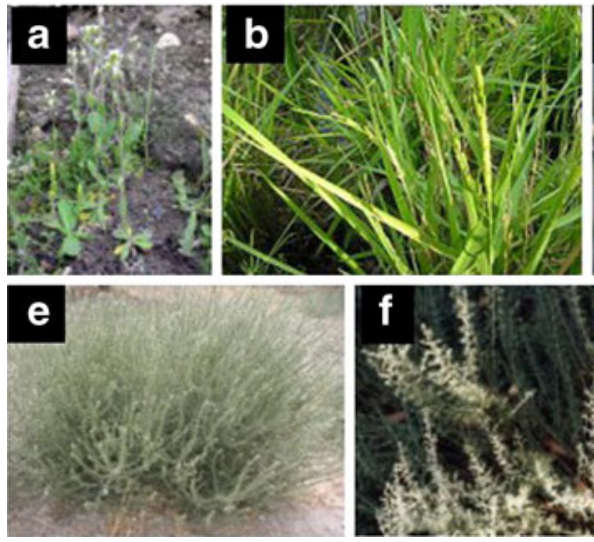

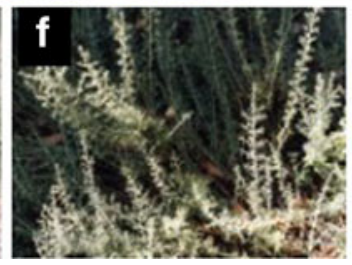

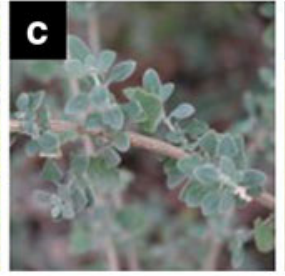

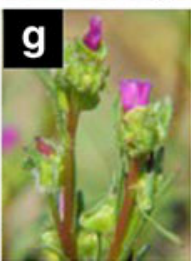

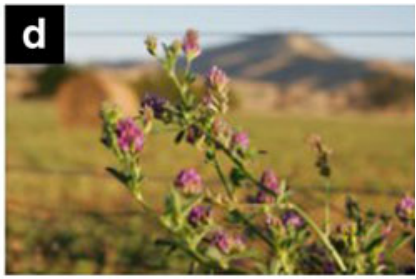

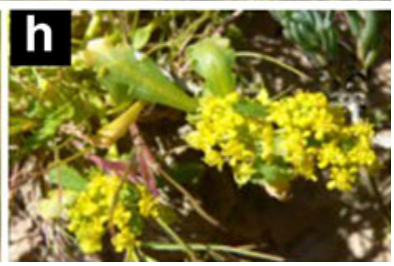

2 Morphological features and development of arbuscular mycorrhizal symbiosis

The arbuscular mycorrhizal fungi are the most complex group of mycorrhizas which forms intraradical and extraradical structures (Fig. 2): (1) intracellular hyphae forming coils, often found in the outer layers of cortical parenchyma, (2) the intercellular hyphae, (3) the intracellular hyphae with numerous ramifications, i.e., the arbuscules, (4) the inter or intracellular hypertrophied hyphae, i.e., the vesicles, (5) the extracellular ramified hyphae, i.e., branched-absorbing structures (BAS), and (6) resistance propagules, i.e., the spores.

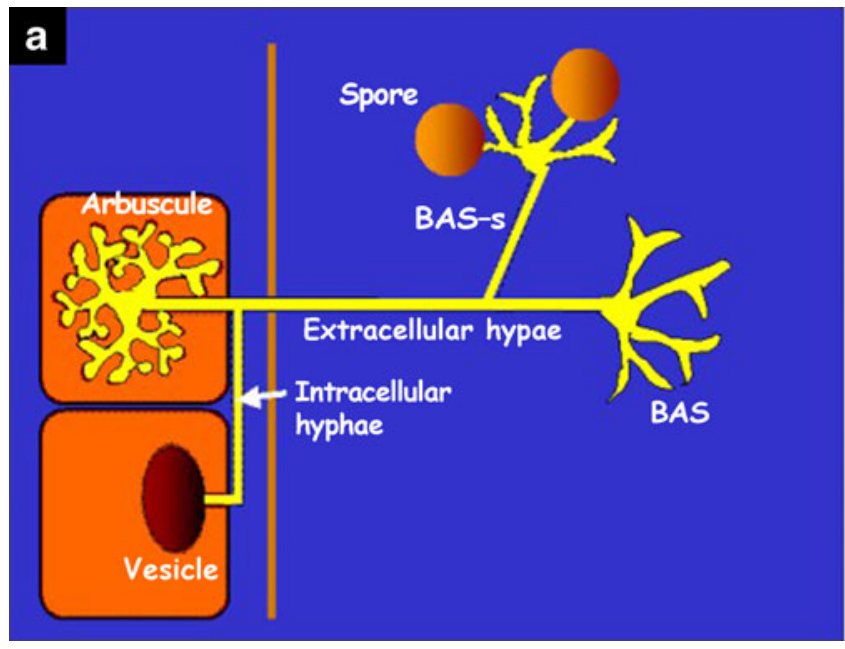

Fig. 2 a Schematic representation of arbuscular mycorrhizal symbiosis. Courtesy of Dr. A. Bago (CSIC, Spain). b Part of a clover root showing the distribution of fungal structures in the root. The main features shown are root hairs (rh) an entry point with a characteristic

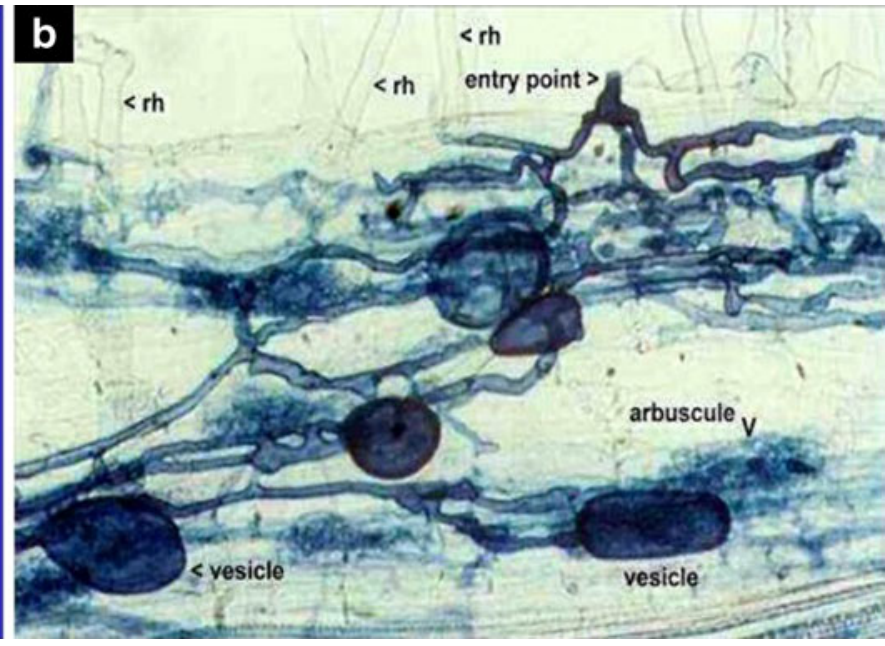

diamond-shaped swelling equivalent to an appressorium, large swollen vesicles, and "fuzzy" arbuscules. Courtesy of Dr. Jim Deacon (The University of Edinburgh) 
Arbuscular mycorrhizal fungal spores are able to germinate in the absence of the host, but are unable to produce extensive mycelia and to complete their life cycle without establishing a functional symbiosis with a host plant. The lack of host-regulated spore germination did not represent a selective disadvantage, since AM fungi coevolved with heir host plants for more than 360 and 400 million years (Remy et al. 1994; Redecker et al. 2000). Different efficient survival strategies have been inferred to be active in these ancestral organisms to compensate for the lack of host-regulated spore germination, e.g., a wide host range (Smith and Read 1997), the regulation of infection structure differentiation (Giovannetti et al. 1994), the ability of multiple germination (Koske 1981), an energy-saving mechanism operating when spores germinate in the absence of the host (Logi et al. 1998). In addition to these strategies, the ability to form wide hyphal networks by both presymbiotic and symbiotic mycelia may represent a fundamental mechanism for increasing the chances of AM symbionts to contact host roots (Giovannetti et al. 1999).

The establishment of the AM symbiosis begins with the colonization of a compatible root by the hyphae produced by AM fungal soil propagules, asexual spores or mycorrhizal roots. Even dead roots from annual plants might be a good source of inoculum because they protect the fungus from environmental hazards until the time when new hyphae can grow out of the roots and colonize other plants (Requena et al. 1996). After attachment of a hypha to the root surface by means of an appressorium, the fungus penetrates into the cortex and forms distinct morphologi- cally specialized structures: Inter- and intracellular hyphae, coils, and arbuscules. Arbuscules are specialized hyphae similar to haustoria from plant pathogenic fungi. They are presumed to be the main site of nutrient exchange between the plant and the fungus (He and Nara 2007). After host colonization, the fungal mycelium grows out of the root exploring the soil in search of mineral nutrients, and it can also colonize other susceptible roots (Breuninger and Requena 2004). The fungal life cycle is completed after formation of asexual chlamydospores on the external mycelium (Fig. 3).

\section{Ecological significance of arbuscular mycorrhizal symbiosis}

Ecological consequences of the interactions between plants and the AMF for plant nutrition, growth, competition, stress tolerance and fitness, as well as for soil structuring have been often addressed. The key effects of AM symbiosis can be summarized as follows: (1) enhancing uptake of low mobile ions, (2) improving quality of soil structure, (3) enhancing plant community diversity, (4) improving rooting and plant establishment, (5) improving soil nutrient cycling, and (6) enhancing plant tolerance to (biotic and abiotic) stress (Smith and Read 2008).

The contribution of AMF to plant nutrient uptake is mainly through the acquisition of nutrients (especially phosphorous, which is extremely immobile element in soils) from the soil by the extraradical fungal hyphae,
Fig. 3 Schematic representation of distinct morphological stages identified during the life cycle of arbuscular mycorrhizal fungi

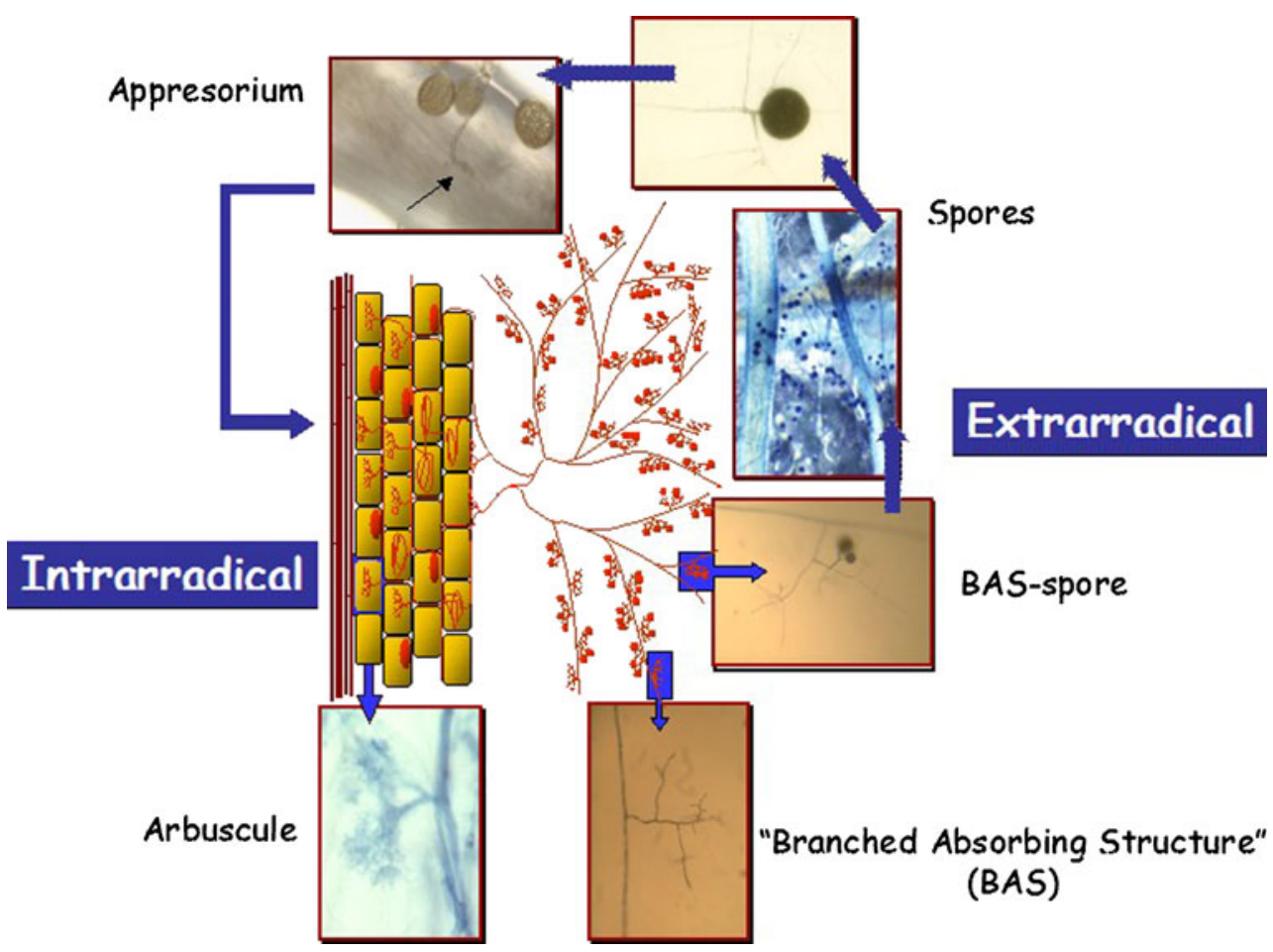


especially from root-distant soil not depleted of nutrients by the root. Fungal hyphae are functionally analogous to fine root hairs, as both are nutrient uptake organs. Mycelium extends the plant's effective absorption surfaces beyond the nutrient depleted zone that develops around the root caused by direct root uptake processes (George 2000).

As a result of degradation/desertification processes, disturbance of natural plant communities is often accompanied, or preceded by lost of physicochemical and biological properties of the soil, such as soil structure, plant nutrient availability, organic matter content, and microbial activity. Therefore, in degraded and contaminated soils, that are often poor in nutrients and with low waterholding capacities, management of AM fungi is of great importance (Jeffries and Barea 2001). The effect of the AM fungi in cooperation with other microbes in the formation of water-stable soil aggregates is evident in different ecological situations (Andrade et al. 1995, 1998; Bethlenfalvay and Schüepp 1994; Bethlenfalvay et al. 1999; Requena et al. 2001), and the involvement of glomalin, a glycoprotein produced by the external hyphae of AM fungi, has been demonstrated (Wright and Upadhyaya 1998). Because of its glue-like hydrophobic nature, glomalin participates in the initiation and stabilization of soil aggregates (Miller and Jastrow 2000).

The influence of mycorrhizas on plant competition can be expected to lead to changes in plant coexistence and biodiversity. The microcosm experiment of Grime et al. (1987) provided one of the first clear demonstrations that AM fungi are potentially major determinants both of the structure and diversity of plant assemblages. Similar results have been obtained more recently by Van der Heijden et al. (1998) showing not only increased diversity, but also increased productivity, which was not observed in the experiments of Grime et al. (1987). The effect of arbuscular mycorrhizal in increasing diversity was the result of improved growth and survivorship of AM subordinates, associated with dominants that actually had their own competitive ability reduced by AM colonization.

The well-known activities of nitrogen-fixing bacteria and phosphate-solubilizing microorganisms improving the bioavailability of the major plant nutrients $\mathrm{N}$ and $\mathrm{P}$, are very much enhanced in the rhizosphere of mycorrhizal plants where synergistic interactions of such microorganisms with mycorrhizal fungi have been demonstrated (Barea et al. 2002). AM mycelia have been shown to affect not only root morphology and functioning but also improve mycorrhizosphere soil properties.

AM symbiosis has been shown to increase tolerance to biotic and abiotic stresses. Regarding abiotic stress, several studies for years have demonstrated that AM symbiosis confers tolerance to drought (for reviews see Ruiz-Lozano 2003; Miransari 2010), heat (Compant et al.
2010), salinity (Evelin et al. 2009; Miransari 2010) or osmotic stress (Ruiz-Lozano 2003). On the other hand, early works on mycorrhizas and biotic stresses were mostly descriptive (for review, see Linderman 2000). A recent review by Pozo and Azcón (2007) summarizes the data on AM-induced protection against biotic stress and the possible mechanisms involved, with special emphasis on the role of plant defense responses. Generally, reports have focussed on beneficial effects of the symbiosis, aiming at using $\mathrm{AM}$ as potential biocontrol agents in integrated management programmes for disease control (Mukerji and Ciancio 2007). AM symbiosis has also been shown to occur in almost all habitats, including disturbed soils contaminated with heavy metals, and plays an important role in metal tolerance. A number of different mechanisms may be involved, including tissue dilution of the toxic element due to interactions with $\mathrm{P}$ nutrition and growth, sequestration of the toxic metal in the fungus and development of tolerance by the fungi (for reviews, see Hildebrandt et al. 2007; Gamalero et al. 2009). Thus, we can conclude that some plants are unable to endure habitat-imposed abiotic and biotic stresses in the absence of fungal endophytes.

\section{Salinity effects on plants}

Soil salinity affects the establishment, growth, and development of plants leading to huge losses in productivity (Evelin et al. 2009). Plants growing in saline soil are subjected to three distinct physiological stresses. First, the toxic effects of specific ions such as sodium and chloride, prevalent in saline soils, disrupt the structure of enzymes and other macromolecules, damage cell organelles, disrupt photosynthesis and respiration, inhibit protein synthesis, and induce ion deficiencies (Juniper and Abbott 1993). Second, plants exposed to the low osmotic potentials of saline soil are at risk of physiological drought because they must maintain lower internal osmotic potentials to prevent water moving from the roots into the soil. Finally, salinity also produces nutrient imbalance in the plant caused by decreased nutrient uptake and/or transport to the shoot (Marschner 1995; Adiku et al. 2001). As a consequence, salt stress affects all the major processes, such as growth, photosynthesis, protein synthesis, and energy and lipid metabolisms (Ramoliya et al. 2004).

A generic stress signal transduction pathway for the plant stress response is depicted in Fig. 4. The stress signal is first perceived at the membrane level by the receptor, which results in the generation of secondary signal molecules, such as $\mathrm{Ca}^{2+}$, inositol phosphates, reactive oxygen species (ROS) and abscisic acid (ABA). The stress signal then transduces inside the nucleus to induce multiple 
Fig. 4 Generic pathway for plant stress response. The extracellular stress signal is first perceived by the membrane receptor and then activates a large and complex signalling cascade intracellularly. The signal cascade results in the expression of multiple stress responsive genes, the products of which can provide the stress tolerance directly or indirectly. Overall, the stress response could be a coordinated action of many genes. Adapted from Tuteja (2007) with kind permission from Elsevier

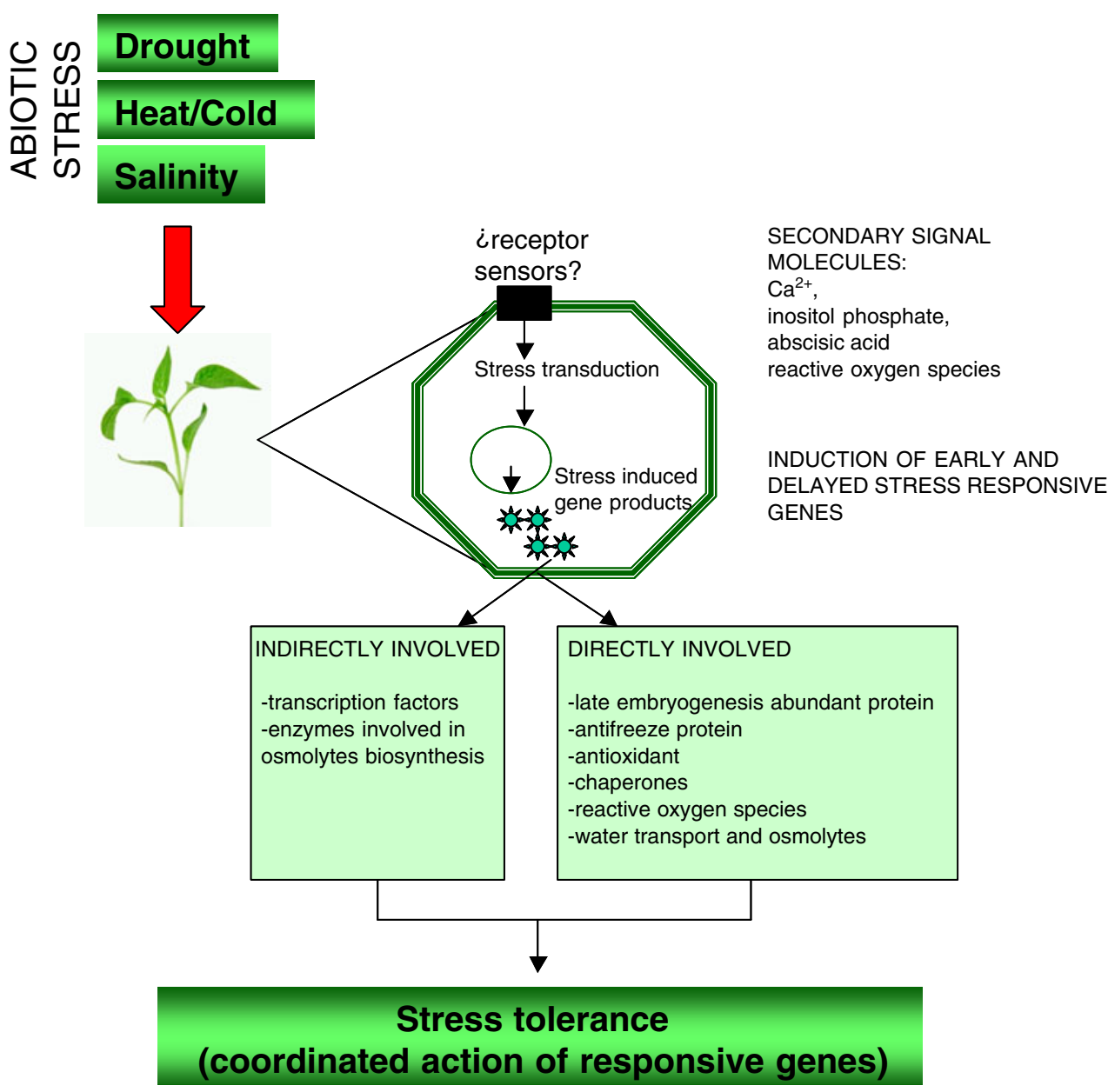

stress responsive genes, the products of which ultimately lead to plant adaptation to stress tolerance. Early genes are induced within minutes of stress perception, and their products (e.g., various transcription factors) can activate the expression of delayed genes (e.g., RD [responsive to dehydration], KIN [cold induced], COR [cold responsive]). Overall, gene products are either involved directly in cellular protection against the stress (e.g., late embryogenesis abundant proteins, antifreeze proteins, antioxidants, chaperons, and detoxification enzymes) or involved indirectly in protection (e.g., transcription factor, enzymes of phosphatidylinositol metabolism; Tuteja 2007).

\section{Salinity effects on arbuscular mycorrhizal fungi}

Salinity, not only affects negatively the host plant but also the AMF. It can hamper colonization capacity, spore germination, and growth of fungal hyphae. Colonization of plant roots by some AMF is reduced in the presence of $\mathrm{NaCl}$ (Hirrel and Gerdemann 1980; Ojala et al. 1983; Poss et al. 1985; Duke et al. 1986; Rozema et al. 1986; Menconi et al. 1995; Juniper and Abbott 2006; Giri et al. 2007; Sheng et al. 2008) probably due to the direct effect of $\mathrm{NaCl}$ on the fungi (Juniper and Abbott 2006) indicating that salinity can suppress the formation of arbuscular mycorrhiza (Tian et al. 2004; Sheng et al. 2008). The varying levels of AM colonization under saline conditions may also be related to the different behaviour of each AM fungal species, even in similar ecosystems (Kilironomos et al. 1993) or to the influence of different environmental conditions (Carvalho et al. 2001).

In the presence of $\mathrm{NaCl}$, germination of spores is delayed rather than prevented (Cantrell and Linderman 2001; Juniper and Abbott 2006). The rate of germination and maximum germination of AMF spores may also depend on the salt type. According to Juniper and Abbott (1993), the different salts $\mathrm{NaNO}_{3}$ and $\mathrm{Na}_{2} \mathrm{SO}_{4}$ with similar osmotic potentials impart differential effects on the rate and maximum germination of spores. They attributed the difference to a higher concentration of $\mathrm{Na}^{+}$in the latter.

Jahromi et al. (2008) studied in vitro the effects of salinity on the AM fungus, Glomus intraradices. They observed that there was no significant difference in hyphal length and BAS between control (no salt) and $50 \mathrm{mM}$ $\mathrm{NaCl}$, though there was a significant decrease in hyphal length and the number of BAS at $100 \mathrm{mM} \mathrm{NaCl}$ (Table 1). 
Table 1 Total hyphal length and number of spores and branched absorbing structures (BAS) formed by $G$. intraradices grown in monoxenic culture and subjected to 0,50 , or $100 \mathrm{mM} \mathrm{NaCl}$

\begin{tabular}{lllll}
\hline & \multicolumn{3}{c}{ Salt level } \\
\cline { 2 - 4 } & $0 \mathrm{mM}$ & $50 \mathrm{mM}$ & $100 \mathrm{mM}$ & LSD \\
\hline Hyphal length (sqrt mm cm & & \\
& & & \\
Number of spores $\left(\mathrm{cm}^{-2}\right)$ & $48.4 \mathrm{a}$ & $42.6 \mathrm{a}$ & $30.7 \mathrm{~b}$ & 10.9 \\
Number of Bas & $59.5 \mathrm{a}$ & $14.0 \mathrm{~b}$ & $11.0 \mathrm{~b}$ & 29.4 \\
\hline
\end{tabular}

Data were subjected to analysis of variance (ANOVA) and followed by the Fisher's less significant Differences test (5\% of significance). Table reproduced from Jahromi et al. (2008) with kind permission from Springer Science and Business Media

Means followed by different letters are significantly different $(P<0.05)$

LSD less significant difference, sqrt square root

Thus, all these results demonstrate that salinity affects directly the fungal development, reducing fungal mycelia formation and host root colonization.

Contrary to the reports above, increased AMF sporulation and colonization under salt stress conditions has also been reported (Aliasgharzadeh et al. 2001). Recently, Yamato et al. (2008) reported that colonization rates were not reduced in all AMF present in coastal vegetation on Okinawa Island, Japan even when treated with high salinity of $200 \mathrm{mM}$. This discrepancy in the results invites researchers to look out for salt-tolerant AMF species and to test if these AM isolates maintain colonization capacity and symbiosis efficiency under saline conditions.

\section{Arbuscular mycorrhizal effects on plant biomass and nutrient uptake}

Several studies investigating the role of AMF in protection against salt stress have demonstrated that the symbiosis often results in increased nutrient uptake, accumulation of osmoregulator compounds, and increase in photosynthetic rate and water use efficiency, suggesting that salt stress alleviation by AMF results from a combination of nutritional, biochemical, physiological, and molecular effects. However, this positive effect on plant development depends on the AMF species involved (Marulanda et al. 2003, 2007; Wu et al. 2007).

Hence, mycorrhization was found to increase the fitness of the host plant by enhancing its growth. Several researchers have reported that AMF-inoculated plants grow better than non-inoculated plans under salt stress (Al-Karaki 2000; Cantrell and Linderman 2001; Giri et al. 2007; Sannazzaro et al. 2007; Zuccarini and Okurowska 2008). For instance, Hajiboland et al. (2010) have recently reported that although high salinity reduced dry matter production by two tomato cultivars, in all treatments mycorrhizal plants grew better than nonmycorrhizal plants (Fig. 5).

The mycorrhizal association is well known to increase host nutrient acquisition, particularly P (Smith and Read 1997). The improved growth of mycorrhizal plants in saline conditions is primarily related to mycorrhiza-mediated enhancement of host plant P nutrition (Hanway and Heidel 1952; Hirrel and Gerdemann 1980; Ojala et al. 1983; Pond et al. 1984; Poss et al. 1985; Al-Karaki 2000).
Fig. 5 Influence of different salinity levels on shoot and root dry weights (DW) of tomato cultivars Behta and Piazar colonized (+AMF) or not $(-\mathrm{AMF})$ with an arbuscular mycorrhizal fungus (AMF). Bars of each parameter labeled by different letters indicate significant differences assessed by the

Bonferroni test after performing three-way ANOVA $(P<0.05)$. Adapted from Hajiboland et al. (2010) with kind permission from Springer Science and Business Media
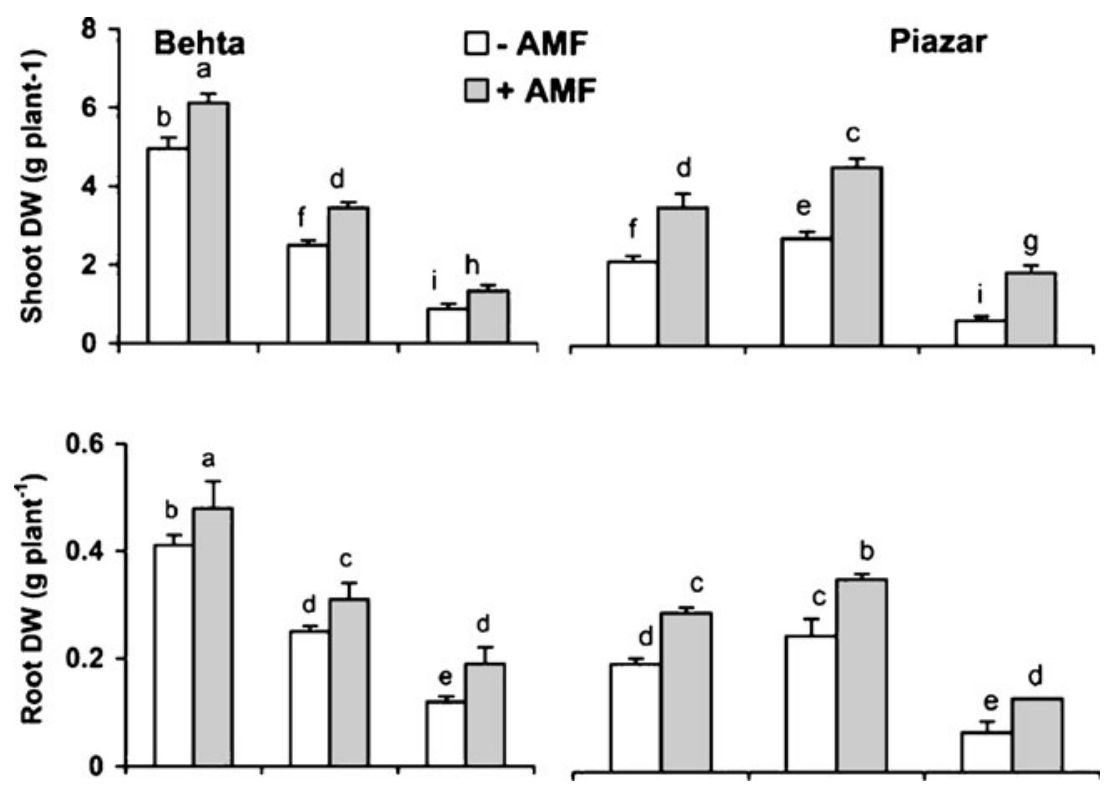
Beneficial effect of $\mathrm{Na}^{+}$on growth of nonhalophytes was reported for some natrophilic crop species such as sugar beet (Marschner et al. 1981; Hajiboland et al. 2009) and was attributed mainly to an ability of plants for replacement of $\mathrm{K}^{+}$by $\mathrm{Na}^{+}$(Marschner et al. 1981; Hajiboland and Joudmand 2009). Elevated $\mathrm{Na}^{+}$in soil solution inhibits the uptake of other nutrients by disrupting the uptake of nutrients directly by interfering with various transporters in the root plasma membrane, such as $\mathrm{K}^{+}$-selective ion channels, and inhibiting root growth by the osmotic effects of $\mathrm{Na}^{+}$on soil structure (Wild 1988). Thus, the uptake of water and essential mineral nutrients, such as $\mathrm{P}, \mathrm{K}, \mathrm{Fe}, \mathrm{Cu}$, and $\mathrm{Zn}$, and the population of soil bacteria can be reduced (Barea et al. 2005). Certain ion ratios, such as $\mathrm{K} / \mathrm{Na}$, are accepted indicators for evaluation of salinity tolerance in tomato cultivars (Dasgan et al. 2002). Moreover, high $\mathrm{Na}^{+} / \mathrm{K}^{+}$ratio disrupts various metabolic processes such as protein synthesis in the cytoplasm (Tester and Davenport 2003). Giri et al. (2007) showed that Acacia nilotica plants colonized by G. fasciculatum had a higher concentration of $\mathrm{K}^{+}$in root and shoot tissues at all salinity levels assayed. Similar increase in the concentration of $\mathrm{K}^{+}$has also been reported previously (Hanway and Heidel 1952; Ojala et al. 1983; Mohammad et al. 2003). It seems that higher $\mathrm{K}^{+}$accumulation by mycorrhizal plants under salt stress conditions may help in maintaining a high $\mathrm{K} / \mathrm{Na}$ ratio, thus preventing the disruption of various enzymatic processes and inhibition of protein synthesis.

Apart from $\mathrm{P}$ and $\mathrm{K}$, it has been demonstrated that arbuscular mycorrhizal fungi have a positive influence on the composition of mineral nutrients of plants grown under salt stress conditions (Al-Karaki and Clark 1998) by enhancing and/or selective uptake of nutrients. A number of studies have shown the effect of salinity on the nutrient uptake of mycorrhizal plants (Table 2).

\section{Biochemical changes}

The best characterized biochemical response of plant cells to osmotic stress is accumulation of some inorganic ions such as $\mathrm{Na}^{+}$and compatible organic solutes like proline, glycine betaine, and soluble sugars (Flowers and Colmer 2008). These compatible solutes can accumulate to high levels without disturbing intracellular biochemistry (Bohnert and Jensen 1996), protecting sub-cellular structures, mitigating oxidative damage caused by free radicals, and maintaining the enzyme activities under salt stress (Yokoi et al. 2002).

\subsection{Proline and other osmolytes}

One of the main consequences of $\mathrm{NaCl}$ stress is the loss of intracellular water. Plants accumulate many metabolites that are also known as "compatible (organic) solutes" in the cytoplasm to increase their tolerance against salt stress-induced water loss from the cells. Among these compounds, proline, betaines, sugars (chiefly fructose, sucrose and glucose) and complex sugars (trehalose, raffinose, and fructans) have been suggested to accomplish this function in halophytes.

Proline and glycine betaine $(\mathrm{N}, \mathrm{N}, \mathrm{N}$-trimethylglycine betaine) are two major osmoprotectant osmolytes, which are synthesized by many plants (but not all) in response to stress, including salinity stress, and thereby help in maintaining the osmotic status of the cell to ameliorate the abiotic stress effect. Proline also plays roles in scavenging free radicals, stabilizing subcellular structures, and buffering cellular redox potential under stresses. The salinity stress responsive genes, whose promoters contain proline responsive elements (ACTCAT), are also known to be induced by proline (Chinnusamy et al. 2005). In higher plants, proline is synthesized from glutamic acid by the actions of two enzymes, pyrroline-5-carboxylate synthetase (P5CS) and pyrroline-5-carboxylate reductase (P5CR). Overexpression of the P5CS gene in transgenic tobacco resulted in increased production of proline and salinity/ drought tolerance (Kishor et al. 1995).

Proline accumulation, in terms of amount, has been found to increase when the plant is colonized by AMF. Several authors have reported a higher proline concentration in AM plants than in non-AM plants at different salinity levels (Jindal et al. 1993; Sharifi et al. 2007). However, in contrast to the reports above, other authors reported that non-MA plants accumulated more proline that AM plants at various salinity levels (Wang et al. 2004; Rabie and Almadini 2005; Jahromi et al. 2008), suggesting that proline accumulation in plants may be a sympton of stress in less salt-tolerant species or that this accumulation may be also due to salinity and not necessarily to mycorrhizal colonization.

On the other hand, betaines can also stabilize the structures and activities of enzymes and protein complexes and maintain the integrity of membranes against the damaging effects of excessive salt (Gorham 1995). Accumulation of betaines under salt stress was found to increase when the plant is colonized by AMF (Al-Garni 2006).

The increase in sugar content is found to be positively correlated with mycorrhization of the host plant as reported by Thomson et al. (1990). Porcel and Ruiz-Lozano (2004) also reported increased sugar concentrations in soybean roots colonized by $G$. intraradices and subjected to drought stress. The positive correlation between sugar content and mycorrhization is due to the sink effect of the fungus demanding sugars from the shoot tissues (Augé 2000). Moreover, the increased sugar accumulation may also be due to hydrolysis of starch to sugars in the seedlings 
Table 2 Some examples of increased/decreased nutrient uptake in AM plants under salinity stress

\begin{tabular}{|c|c|c|c|c|c|}
\hline Nutrient & Range of salinity ${ }^{\mathrm{a}}$ & Plant & Fungus & Effect & References \\
\hline \multirow[t]{7}{*}{ Phosphorus } & $0-24.6 \mathrm{dS} \mathrm{m}^{-1}(0-200 \mathrm{mM})$ & Glycine $\max$ & Glomus etunicatum & Increase & Sharifi et al. (2007) \\
\hline & $1 \cdot 2-9 \mathrm{ds} \mathrm{m}^{-1}$ & Acacia nilotica & Glomus fasciculatum & Increase & Giri et al. (2007) \\
\hline & $0-19 \cdot 12 \mathrm{dS} \mathrm{m}^{-1}(0-150 \mathrm{mM})$ & Citrus karma & $\begin{array}{l}\text { Mixed inoculum of } \\
\text { Glomus } s p \text {. and } \\
\text { Gigaspora sp. }\end{array}$ & Increase & Murkute et al. (2006) \\
\hline & $0-6 \cdot 10 \mathrm{dS} \mathrm{m}^{-1}\left(0-3 \mathrm{~g} \mathrm{~kg}^{-1}\right)$ & Gossypium arboreum & Glomus mosseae & Increase & Tian et al. (2004) \\
\hline & $3-10 \mathrm{ds} \mathrm{m}^{-1}\left(0 \cdot 3-1 \cdot 0 \mathrm{~S} \mathrm{~m}^{-1}\right)$ & Acacia auriculiformis & $\begin{array}{l}\text { Glomus macrocarpum } \\
\text { and Glomus fasciculatum }\end{array}$ & Increase & Giri et al. (2003) \\
\hline & $0-13 \cdot 19 \mathrm{dS} \mathrm{m}^{-1}(0-100 \mathrm{mM})$ & Zea mays & Glomus mosseae & Increase & Feng et al. (2002) \\
\hline & $1-7 \cdot 4 \mathrm{dS} \mathrm{m}^{-1}$ & $\begin{array}{l}\text { Lycoperssicon } \\
\text { esculentum }\end{array}$ & Glomus mosseae & Increase & Al-Karaki (2000) \\
\hline \multirow[t]{3}{*}{ Nitrogen } & $4-8 \mathrm{dS} \mathrm{m}^{-1}$ & Cajanus cajan & Glomus mosseae & Increase & Garg and Manchanda (2008) \\
\hline & $0-19 \cdot 12 \mathrm{dS} \mathrm{m}^{-1}(0-150 \mathrm{mM})$ & Citrus karma & $\begin{array}{l}\text { Mixed inoculum } \\
\text { of Glomus sp. and } \\
\text { Gigaspora sp. }\end{array}$ & Increase & Murkute et al. (2006) \\
\hline & $15.8 \mathrm{dS} \mathrm{m}^{-1}\left(1.58 \mathrm{~S} \mathrm{~m}^{-1}\right)$ & Sesbania aegyptiaca & Glomus macrocarpum & Increase & Giri and Mukerji (2004) \\
\hline \multirow[t]{2}{*}{ Potassium } & $0-7.56 \mathrm{dS} \mathrm{m}^{-1}\left(0-3 \mathrm{~g} \mathrm{~L}^{-1}\right)$ & Ocimum basilicum & Glomus intraradices & Increase & Zuccarini and Okurowska (2008) \\
\hline & $2-24.6 \mathrm{dS} \mathrm{m}^{-1}(0-200 \mathrm{mM})$ & Glycine $\max$ & Glomus etunicatum & Increase & Sharifi et al. (2007) \\
\hline \multirow[t]{2}{*}{ Calcium } & $0-24.6 \mathrm{dS} \mathrm{m}^{-1}(0-200 \mathrm{mM})$ & Glycine $\max$ & Glomus etunicatum & Increase & Sharifi et al. (2007) \\
\hline & $0.72-7.39 \mathrm{dS} \mathrm{m}^{-1}$ & Musa sp. & Glomus clarum & Increase & Yano-Melo et al. (2003) \\
\hline Magnesium & $15.8 \mathrm{dS} \mathrm{m}^{-1}\left(1.58 \mathrm{~S} \mathrm{~m}^{-1}\right)$ & Sesbania aegyptiaca & Glomus macrocarpum & Increase & Giri and Mukerji (2004) \\
\hline \multirow[t]{6}{*}{ Sodium } & $1 \cdot 2-9.5 \mathrm{dS} \mathrm{m}^{-1}$ & Acacia nilotica & Glomus fasciculatum & Increase & Giri et al. (2007) \\
\hline & $0-6 \cdot 10 \mathrm{dS} \mathrm{m}^{-1}\left(0-3 \mathrm{~g} \mathrm{~kg}^{-1}\right)$ & Gossypium arboreum & Glomus mosseae & Increase & Tian et al. (2004) \\
\hline & $0 \cdot 12 \mathrm{~S} \mathrm{~m}^{-1}$ & Acacia auriculiformis & $\begin{array}{l}\text { Glomus macrocarpum } \\
\text { and Glomus fasciculatum }\end{array}$ & Increase & Giri et al. (2003) \\
\hline & $0-7.56 \mathrm{dS} \mathrm{m}^{-1}\left(0-3 \mathrm{~g} \mathrm{~L}^{-1}\right)$ & Ocimum basilicum & Glomus intraradices & Decrease & Zuccarini and Okurowska (2008) \\
\hline & $0-24 \cdot 6 \mathrm{dS} \mathrm{m}^{-1}(0-200 \mathrm{mM})$ & Glycine $\max$ & Glomus etunicatum & Decrease & Sharifi et al. (2007) \\
\hline & $1.4-7.4 \mathrm{dS} \mathrm{m}^{-1}$ & Lycopersicon esculentum & Glomus mosseae & Decrease & Al-Karaki (2000) \\
\hline \multirow[t]{2}{*}{ Chloride } & $0-6 \cdot 10 \mathrm{dS} \mathrm{m}^{-1}\left(0-3 \mathrm{~g} \mathrm{~kg}^{-1}\right)$ & Gossypium arboreum & Glomus mosseae & Increase & Tian et al. (2004) \\
\hline & $0-7.56 \mathrm{dS} \mathrm{m}^{-1}\left(0-\mathrm{g} \mathrm{L}^{-1}\right)$ & Ocimum basilicum & Glomus intraradices & Decrease & Zuccarini and Okurowska (2008) \\
\hline \multirow[t]{2}{*}{ Copper } & $1 \cdot 2-9.5 \mathrm{dS} \mathrm{m}^{-1}$ & Acacia nilotica & Glomus fasciculatum & Increase & Giri et al. (2007) \\
\hline & $1 \cdot 4-7 \cdot 4 \mathrm{dS} \mathrm{m}^{-1}$ & Lycopersicon esculentum & Glomus mosseae & Decrease & Al-Karaki (2000) \\
\hline \multirow[t]{2}{*}{ Zinc } & $0-24.6 \mathrm{ds} \mathrm{m}^{-1}(0-200 \mathrm{mM})$ & Glycine $\max$ & Glomus etunicatum & Increase & Sharifi et al. (2007) \\
\hline & $1 \cdot 4-7 \cdot 4 \mathrm{ds} \mathrm{m}^{-1}$ & Lycopersicon esculentum & Glomus mosseae & Decrease & Al-Karaki (2000) \\
\hline
\end{tabular}

Reproduced from Evelin et al. (2009) with kind permission from Oxford University Press

${ }^{a}$ The range of salinity within brackets is the actual salt concentrations used by the authors

inoculated with mycorrhiza. Conversely, some authors reported negative correlations between AMF colonization and sugar accumulation in host plants. Pearson and Schweiger (1993) reported a reduction in carbohydrate content with an increase in the percentage of root colonization. Sharifi et al. (2007) observed no role of soluble carbohydrates in the responses of AM (colonized by Glomus etunicatum) soybean plants to salinity.

\subsection{ABA content}

ABA is a phytohormone that regulates plant growth and development and also plays an important role in the response of the plant to abiotic stress, including salinity stress. It has been documented that mycorrhization can alter the $\mathrm{ABA}$ levels in the host plant (Duan et al. 1996; Ludwig-Muller 2000; Estrada-Luna and Davies 2003). Jahromi et al. (2008) reported lower ABA levels in lettuce plants colonized by $G$. intraradices than that in the non-AM plants (Fig. 6), indicating that AM plants are less strained by imposed salinity stress than non-AM plants and, hence, accumulated less ABA. It seems that the effects of AMF species on ABA content vary with the host plants (Evelin et al. 2009).

\subsection{Antioxidant system}

Many of the degenerative reactions associated with several biotic, abiotic, and xenobiotic stresses are mediated by 


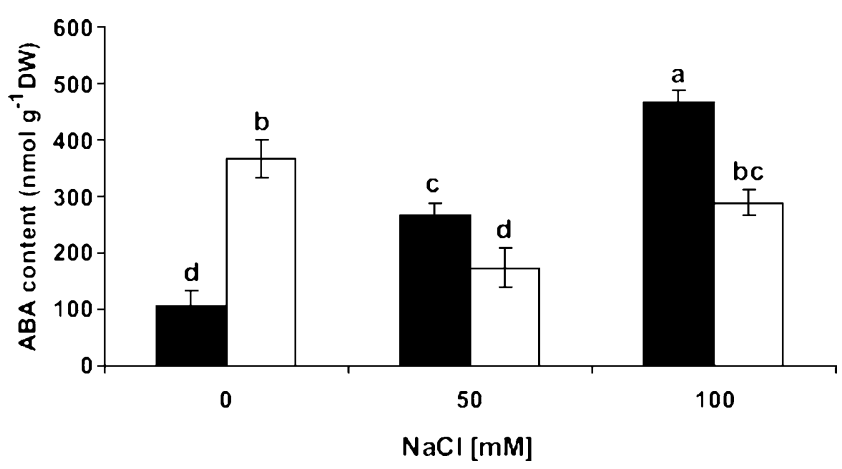

Fig. 6 Abscisic acid content (nmol g dry weight ${ }^{-1}$ ) in lettuce roots. Black columns represent non-inoculated control plants and white columns represent plants inoculated with $G$. intraradices. Plants were subjected to 0.50 and $100 \mathrm{mM} \mathrm{NaCl}$. Columns with different letters are significantly different $(P<0.05)$. Columns represents means \pm SE $(n=6)$. $D W$ dry weight. Data reproduced from Jahromi et al. (2008) with kind permission from Springer Science and Business Media

ROS. The term ROS is generic, embracing not only free radicals such as superoxide $\left(\mathrm{O}^{2-}\right)$ and hydroxyl radicals $\left(\mathrm{OH}^{-}\right)$, but also hydrogen peroxide $\left(\mathrm{H}_{2} \mathrm{O}_{2}\right)$ and singlet oxygen $\left({ }^{1} \Delta_{\mathrm{g}} \mathrm{O}_{2}\right)$. While it is generally assumed that the hydroxyl radical and singlet oxygen are so reactive that their production must be minimized (Jakob and Heber 1996), $\mathrm{O}^{2-}$ and $\mathrm{H}_{2} \mathrm{O}_{2}$ are synthesized at very high rates even under optimal conditions (Noctor and Foyer 1998). The chief toxicity of $\mathrm{O}^{2-}$ and $\mathrm{H}_{2} \mathrm{O}_{2}$ is thought to reside in their ability to initiate cascade reactions that result in the production of the hydroxyl radicals. These radicals (and their derivatives) are among the most reactive species known to chemistry, capable of reacting indiscriminately to cause oxidative damage to biomolecules such as lipid peroxidation, denaturation of proteins, and mutation of DNA (Gutteridge and Halliwell 1989; Bowler et al. 1992). Plant cells contain an array of protective and repair systems that minimize the occurrence of oxidative damage. According to Smirnoff (1993), these can be divided into two categories: systems that react with active forms of oxygen and keep them at a low level [i.e., superoxide dismutases, catalase, or peroxidases], and systems that regenerate oxidized antioxidants [glutathione (GSH), glutathione reductase (GR), ascorbate, and mono- and dehydroascorbate reductases]. The first group of enzymes are involved in the detoxification of $\mathrm{O}^{2-}$ radicals and $\mathrm{H}_{2} \mathrm{O}_{2}$, thereby preventing the formation of $\mathrm{OH}^{-}$radicals. The GR, as well as the GSH, are important components of the ascorbate glutathione pathway (Fig. 7) responsible for the removal of $\mathrm{H}_{2} \mathrm{O}_{2}$ in different cellular compartments (Dalton 1995; Jiménez et al. 1997). Other non-enzymatic compounds which scavenge activated oxygen species include carotenoids, gluthatione, tocopherols and ascorbic acid (Alguacil et al. 2003; Wu and Xia 2006; Wu et al. 2006).
Like other abiotic stresses, salinity also induces oxidative stress in plants (Santos et al. 2001; Hajiboland and Joudmand 2009). A correlation between antioxidant capacity and $\mathrm{NaCl}$ tolerance has been demonstrated in several plant species (Gossett et al. 1994; Benavides et al. 2000; Núñez et al. 2003). Several studies suggested that AM symbiosis helps plants to alleviate salt stress by enhancing the activities of antioxidant enzymes (Alguacil et al. 2003; Zhong et al. 2007).

\section{Physiological changes}

Salt stress inhibits photosynthetic ability and induces physiological drought in plants, which leads to a decrease in crop production (Pitman and Läuchli 2002). However, there have been very few attempts to study the influence of AMF inoculation on photosynthesis and particularly leaf photochemical properties under salt stress (Sheng et al. 2008). Salinity can affect several physiological mechanisms in the plant such as photosynthetic efficiency, membrane disruption, gas exchange, or water status. Some studies (Aroca et al. 2006; Porcel et al. 2006) have shown that colonization of plant roots by the AM fungus $G$. intraradices prevented leaf dehydration caused by salinity. Lower water saturation deficit and higher turgor potential in AM plants also improves the water status of the plant (Al-Garni 2006; Sheng et al. 2008).

AMF colonization induces an increase in root hydraulic conductivity of the host plants under osmotic stress conditions (Sánchez-Blanco et al. 2004; Aroca et al. 2007). AMFcolonized plants are able to fix more $\mathrm{CO}_{2}$ than noninoculated plants and hence their growth is improved (Querejeta et al. 2007). In addition, in some cases, also their water use efficiency is stimulated independent of changes in

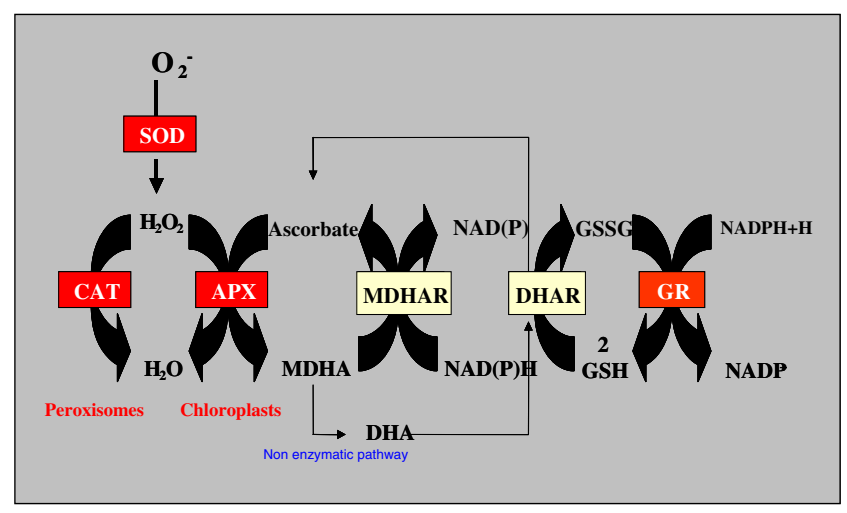

Fig. 7 Ascorbate-gluthation pathway. $S O D$ superoxide dismutase, $C A T$ catalase, $A P X$ ascorbate peroxidase, MDHAR monodehydroascorbate reductase, DHAR dehydroascorbate reductase, $G R$ gluthation reductase, MDHA monodehydroascorbate, GSSG oxidized gluthation, GSH reduced gluthation 
transpiration rate (Bolandnazar et al. 2007). These changes described in transpiration rate by $\mathrm{AM}$ symbiosis are correlated with changes in the $\mathrm{ABA} /$ cytokinins ratio (Goicoechea et al. 1997). At the same time, AMFcolonized plants, by the action of the fungal hyphae, are able to explore more soil and therefore to take up more water from it than noninoculated plants (Marulanda et al. 2003; Khalvati et al. 2005; Bolandnazar et al. 2007).

\section{Molecular changes}

The beneficial effects of the AM symbiosis on plant salinity tolerance have not been only assessed by measuring plant growth or plant water status. At the same time, these beneficial effects have been evidenced by measuring the expression of some plant genes related to salt stress responses.

\subsection{P5CS}

As mentioned previously, proline is probably the most widespread osmoprotectant in plants. Accumulation of proline is mainly due to de novo synthesis, although a reduced rate of catabolism has also been observed (Kishor et al. 1995). The first two steps of proline biosynthesis are catalyzed by P5CS by means of its $\gamma$-glutamil-kinase and glutamic- $\gamma$-semialdehyde-deshydrogenase activities (Fig. 8). Subsequently, the $\Delta^{1}$-pyrroline-5-carboxylate formed is reduced by P5CR to proline (Hu et al. 1992). In Arabidopsis, the P5CS-encoding gene is induced by drought stress, salinity, and ABA, but P5CR is not (Yoshiba et al. 1995). The overexpression of the P5CS-encoding gene in transgenic tobacco plants has been shown to increase proline production and to confer tolerance of such plants to osmotic stress (Kishor et al. 1995). Hence, the P5CS-encoding gene is of key importance for the biosynthesis of proline in plants (Ábrahám et al. 2003).

Investigations carried out so far on osmoregulation in the AM symbiosis are scarce and somewhat contradictory. Moreover, information regarding P5CS gene expression in mycorrhizal plants subjected to salt stress is really limited. Jahromi et al. (2008) reported a higher expression of Lactuca sativa P5CS gene in non-MA plants that in AM

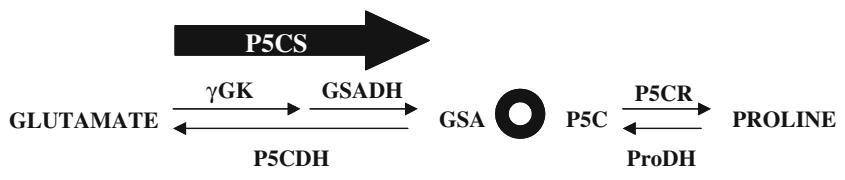

Fig. 8 Pathway of proline biosynthesis. GSA glutamyl- $\gamma$-semialdehyde, P5C $\Delta^{1}$-pyrroline-5-carboxylate, P5CS $\Delta^{1}$-pyrroline-5-carboxylate synthetase, P5CR P5C reductase, $\gamma G K \gamma$-glutamyl kynase, GSADH glutamyl- $\gamma$-semialdehyde deshydrogenase, $P 5 C D H$ P5C deshydrogenase, $\mathrm{ProDH}$ proline deshydrogenase

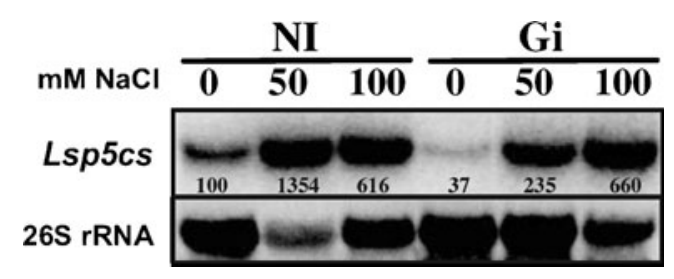

Fig. 9 Northern blot of total RNA $(15 \mu \mathrm{g})$ from lettuce roots using Lsp5cs gene probe. Treatments are designed as NI, noninoculated control, or Gi, plants inoculated with $G$. intraradices. Plants were subjected to 0,50 , or $100 \mathrm{mM} \mathrm{NaCl}$. The lower panels show the amount of $26 \mathrm{~S}$ rRNA loaded for each treatment. Numbers close to each Northern represent the relative gene expression (after normalization to $26 \mathrm{~S}$ rRNA) as a percentage of the value for control plants cultivated under nonsaline conditions. Data adapted from Jahromi et al. (2008) with kind permission from Springer Science and Business Media

plants at $50 \mathrm{mM} \mathrm{NaCl}$, although at $100 \mathrm{mM}$, the levels were similar (Fig. 9).

\subsection{Aquaporins}

The negative water potential in drying or saline soils obliges plants to face with the problem of acquiring sufficient amount of water (Ouziad et al. 2006), a process in which aquaporins participate (Luu and Maurel 2005). Aquaporins are water channel proteins that facilitate and regulate the passive movement of water molecules down a water potential gradient (Kruse et al. 2006). Plants aquaporins are divided in four groups based on their sequence homology. These four groups are called plasma membrane intrinsic proteins (PIPs), tonoplast intrinsic proteins (TIPs), noduline like intrinsic proteins (NIPs), and small and basic intrinsic proteins (SIPs). The localization and function of SIPs are not clear at the moment (Luu and Maurel 2005), although the membrane of endoplasmic reticulum seems to contain SIPs (Ishikawa et al. 2005). Each subgroup is also subdivided, and for example there are PIP1 and PIP2 subgroups, having each subgroup several different proteins. In fact, in Arabidopsis, maize and rice, there are over 30 different aquaporins genes (Chaumont et al. 2001; Johanson et al. 2001; Sakurai et al. 2005). At the same time, each aquaporin group differs in their capacity of transporting water and other small and neutral solutes and in their subcellular localization. For recent reviews, see (Heinen et al. 2009; Maurel et al. 2009; Wudick et al. 2009).

Expression analysis of aquaporin genes in salt-stressed AM plants revealed contrasting results. Aroca et al. (2007) studied four aquaporin genes from $P$. vulgaris in mycorrhizal and nonmycorrhizal plants subjected to three different osmotic stresses: drought, cold, or salinity. Three of these PIP genes showed differential regulation by AM symbiosis under the specific conditions of each stress applied. Salt-treatment induced a higher expression of three $P$. vulgaris PIP genes in both groups of plants, especially in AM ones (Fig. 10). 
On the other hand, Jahromi et al. (2008) reported that in the absence of salinity the expression of L. sativa PIP1 and PIP2 genes was inhibited by mycorrhization, while under saline conditionsmycorrhizal plants maintained the expression of $L s P I P 2$ gene, which was almost unaffected, whereas the expression of LSPIPI gene was upregulated, mainly at $100 \mathrm{mM} \mathrm{NaCl}$. A differential effect of AM symbiosis on aquaporin isoforms under salinity has also been described by Ouziad et al. (2006). In this study, the amount of Lycopersicon esculentum TIP and PIP1 transcripts was

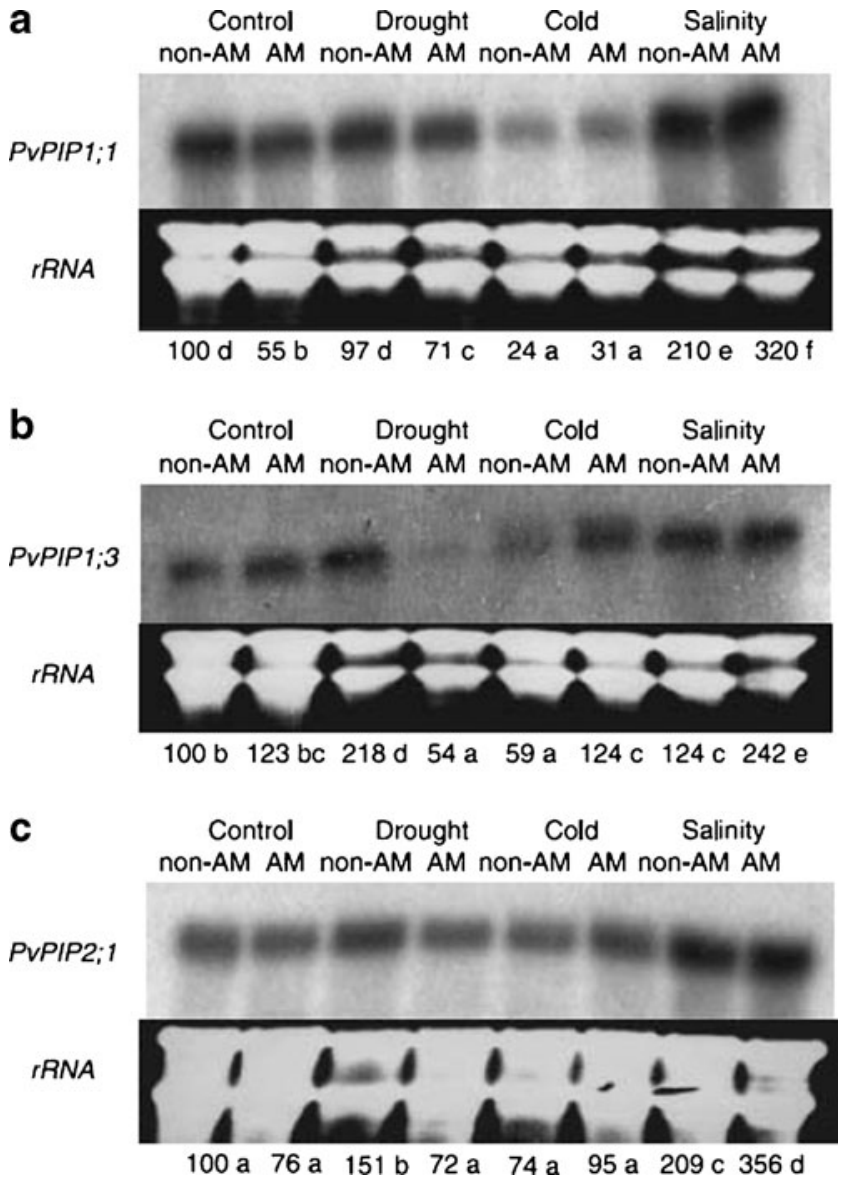

Fig. 10 Northern blot analyses using $3^{\prime}$ untranslated region as probes of Phaseolus vulgaris PIP1;1 (a), PIP1;3 (b), and PIP2;1 (c) in total RNA of $P$. vulgaris roots not inoculated (nonAM) or inoculated (AM) with the arbuscular mycorrhizal fungus Glomus intraradices. Treatments: control plants kept at $23^{\circ} \mathrm{C}$ and watered at full capacity with tap water; drought plants kept at $23^{\circ} \mathrm{C}$ and not watered for 4 days; cold plants transferred to $4^{\circ} \mathrm{C}$ for 2 days and watered at full capacity with tap water; salinity plants kept at $23^{\circ} \mathrm{C}$ and watered every 2 days during a 6-day period with $10 \mathrm{ml}$ of $0.5 \mathrm{M} \mathrm{NaCl}$ solution. Quantification of the gene expression was performed by dividing the intensity value of each band by the intensity of corresponding rRNA stained with ethidium bromide. Control value of nonAM roots was referred as 100 . Treatments with different letters are significantly different $(P<0.05)$ after analysis of variance and Fisher less significant differences test; $n=3$. Data reproduced from Aroca et al. (2007) with kind permission from John Wiley and Sons found to be downregulated in roots and upregulated in leaves of tomato plants subjected to salt stress (Fig. 11).

Hence, results by Aroca et al. (2007), Jahromi et al. (2008), and Ouziad et al. (2006) clearly illustrate that each aquaporin gene may respond differently to AMF colonization and stress imposed. Such differences may be a consequence of the mode of the salt stress set, the differences between plant species tested and the complexity in expression pattern of different members of the large family of aquaporins (Sarda et al. 1999). This highlights the complex regulation of aquaporin genes in response to the $\mathrm{AM}$ symbiosis and to different abiotic stresses with an osmotic component (Table 3).

\subsection{Late embryogenesis abundant proteins}

These are a group of proteins that accumulate in plants seeds during their maturation phase, when tolerance to desiccation is required (Close 1996). It seems that during cellular dehydration, late embryogenesis abundant (LEA) proteins play an important role in maintenance of the structure of other proteins, vesicles, or endomembrane structures in the sequestration of ions such as calcium, in binding or replacement of water, and functioning as molecular chaperones (Close 1996; Koag et al. 2003). The overexpression of LEA proteins in plants and yeast confers tolerance to osmotic stresses (Imai et al. 1996; Xu et al. 1996; Babu et al. 2004). Dehydrins belong to LEA group 2 and represent the most conspicuous soluble proteins induced by a dehydration stress. They have been observed in over 100 independent studies of drought stress, cold acclimation, salinity stress, embryo development, and responses to ABA. However, the existence of multiple targets for dehydrins (euchromatin, cytosol, cytoskeleton) suggests that the direct consequences of dehydrin activity are biochemically diverse.

It is known that LEA gene expression increases under salt stress; however, there are not many studies relating LEA gene expression and MA symbiosis under salt stress conditions. Regarding drought stress, Porcel et al. (2005) cloned two dehydrin-encoding genes from G. max (gmlea8 and gmlea10) and one from L. sativa (lsleal) and analyzed their contribution to the response against drought in mycorrhizal soybean and lettuce plants. Results demonstrate that the levels of lea transcript accumulation in soybean and lettuce plants colonized by either G. mosseae or $G$. intraradices were considerably lower than those of the corresponding nonmycorrhizal plants, suggesting that the accumulation of LEA proteins is not a mechanism by which the AM symbiosis protects their host plant. Moreover, results also suggested that mycorrhizal plants were less strained by drought due to primary drought-avoidance mechanisms. Regarding salinity, Jahromi et al. (2008) reported that LsLea was expressed under conditions of salt 
Fig. 11 Northern hybridizations using total mRNA and the different digoxigenin-labelled riboprobes for three $L$. esculentum aquaporins. Lowest signal intensity of one lane was arbitrary set to 1 to allow a comparison of the signal strengths within one blot (bloc of four lanes) for each gene expressed. Signal strengths were adjusted to the amount of $18 \mathrm{~S}$ rRNA blotted onto each lane. a Root and b leaf. $M$ mycorrhizal plants, $N M$ non-mycorrhizal plants, control plants not stressed with $\mathrm{NaCl}$. Adapted from Ouziad et al. (2006) with kind permission from Elsevier
(A) Root

(B) Leaf

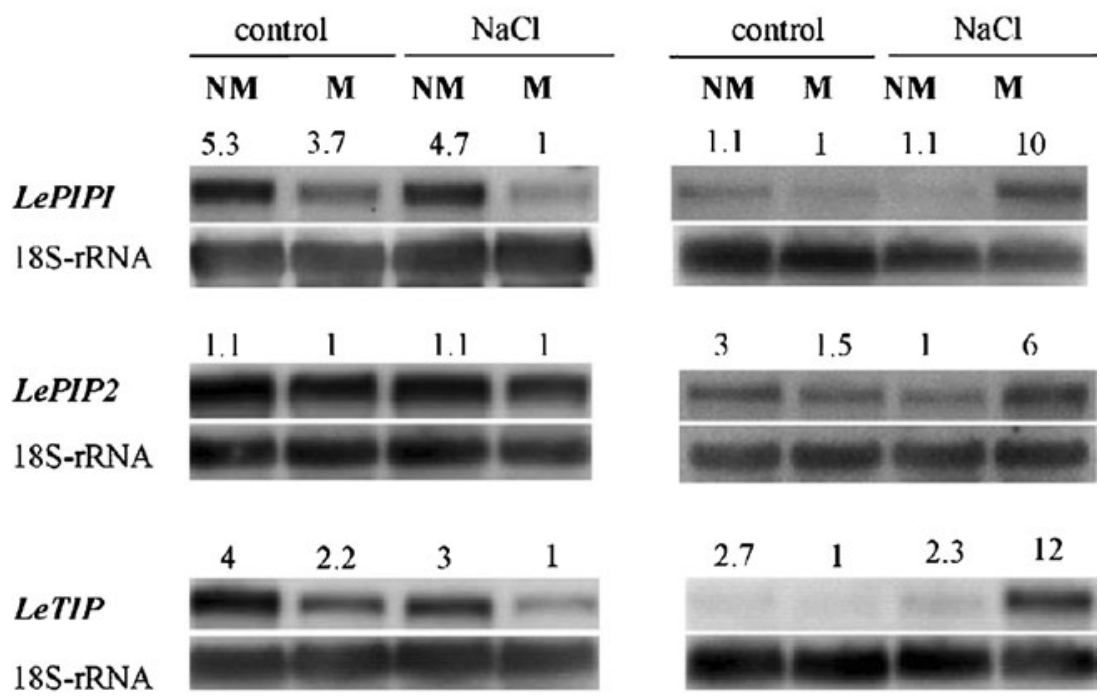

stress and the induction of this gene was also lower in AM plants than in non-MA plants (Fig. 12).

\subsection{Cation channels and transporters}

\subsection{1 $\mathrm{Na}^{+} / \mathrm{H}^{+}$antiporters}

Sodium uptake and distribution within the plant is a major determinant for the salt sensitiveness of a plant. Prevention of
$\mathrm{Na}^{+}$entry into the root, transport to, and allocation within the leaf, and sequestration into the vacuole are strategies by which plants cope with high salt environment. The $\mathrm{Na}^{+} / \mathrm{H}^{+}$ antiporters mediate the transfer of $\mathrm{Na}^{+}$out of the cytoplasm into either vacuole or apoplast. Transgenic plants with overexpressed $\mathrm{Na}^{+} / \mathrm{H}^{+}$antiporters were reported to be more salt tolerant than the controls as shown for Arabidopsis (Gaxiola et al. 1999; Sottosanto et al. 2004) or rice (Fukuda et al. 1999). In Arabidopsis, transporters contributing

Table 3 Summary of the different effects of the mycorrhizal symbiosis on aquaporin gene expression under non stressed or under osmotic stress conditions

\begin{tabular}{|c|c|c|c|c|}
\hline & & & \\
\hline & & \multicolumn{3}{|c|}{ OSMOTIC STRESS } \\
\hline & NO STRESS & DROUGHT & COLD & SALINITY \\
\hline & Source & Source & Source & Source \\
\hline $\begin{array}{l}\text { Mycorrhizal } \\
\text { effects on } \\
\text { aquaporin genes }\end{array}$ & $\begin{array}{l}\text { 4 PcTIP } \quad \text { Roussell et al. } 1997 \\
\text { 4 MtTIP Krajinski et al. } 2000 \\
\text { 4 PttPIP1.1 } \\
\text { 4 PttPIP2.3 Marjanovic et al. } 2005 \\
\text { 4 PuPIPZ.5 } \\
\begin{array}{l}\text { 4 MtPIP2.1 Venkin et al. } 2007 \\
\text { 4 MtNIP1 }\end{array}\end{array}$ & 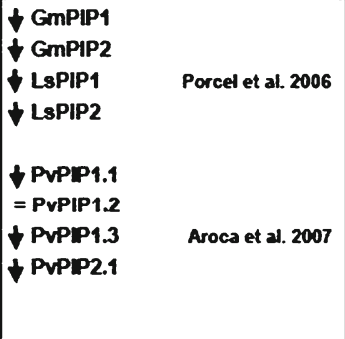 & $\begin{array}{l}\text { † PUPIP1.1 } \\
\text { = PuPIP1.2 } \\
\text { 4 PUPIP1.3 Aroca et al. } 2007 \\
=\text { PuPIP2.1 }\end{array}$ & 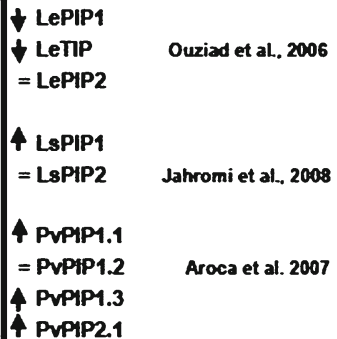 \\
\hline Consequence & $\begin{array}{l}\text { Plant water status not } \\
\text { measured (Roussell et al., } \\
\text { 1997; Krajinski et al., 2000; } \\
\text { Uehlein et al., 2007) } \\
\text { 4Lo (Marjanovic et al., 2005) }\end{array}$ & $\begin{array}{l}\text { 4. (Porcel et al.. 2006) } \\
\text { 4 RWC (Porcel et al., 2006: Aroca } \\
\quad \text { et at.. 2007) } \\
\text { 4 Sap fiow rate (Aroca et al., 2007) }\end{array}$ & $\begin{array}{l}=\text { RWC } \\
=L \quad \quad \text { (Aroca et 21. 2007) } \\
=\text { Sep flow rate }\end{array}$ & 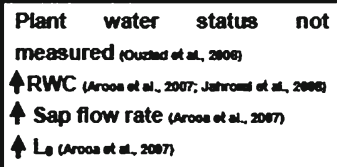 \\
\hline $\begin{array}{l}\text { Proposed } \\
\text { hypothesis }\end{array}$ & $\begin{array}{l}\text { The enhanced aquaporin gene } \\
\text { expression ameliorates the } \\
\text { exchange of water and } \\
\text { nutrients between both } \\
\text { symbiotic partners }\end{array}$ & $\begin{array}{l}\text { The down-regulation by the AM } \\
\text { symbiosis of plant aquaporins } \\
\text { allows conservation of water in } \\
\text { plant tissues under drought }\end{array}$ & $\begin{array}{l}\text { The arbuscular mycorrhizal } \\
\text { fungi have little effect on } \\
\text { plant water relations under } \\
\text { cold stress }\end{array}$ & $\begin{array}{l}\text { The up-regulation of aquaporin } \\
\text { genes improves plant water } \\
\text { flow and water status under } \\
\text { salt stress }\end{array}$ \\
\hline
\end{tabular}

The consequences on plant water relations (when measured) and the proposed hypothesis are also included. Reproduced from Ruiz-Lozano and Aroca (2010) with kind permission from Springer Science and Business Media 


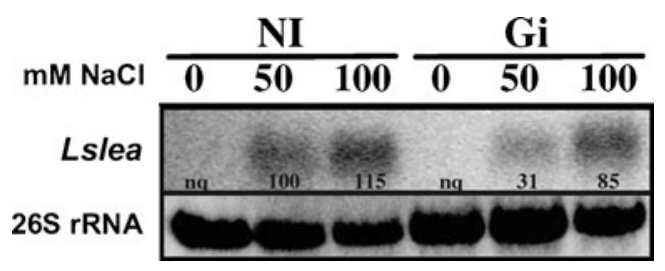

Fig. 12 Northern blot of total RNA $(15 \mu \mathrm{g})$ from lettuce roots using Lslea gene probe. Treatments are designed as NI, noninoculated control, or Gi, plants inoculated with G. intraradices. Plants were subjected to 0,50 , or $100 \mathrm{mM} \mathrm{NaCl}$. The lower panels show the amount of $26 \mathrm{~S}$ rRNA loaded for each treatment. Numbers close to each Northern represent the relative gene expression (after normalization to $26 \mathrm{~S}$ rRNA) as a percentage of the value for control plants, which were set at $100 \%$ in those plants subjected to $50 \mathrm{mM} \mathrm{NaCl}, n q$, not quantifiable. Data adapted from Jahromi et al. (2008) with kind permission from Springer Science and Business Media

to $\mathrm{Na}^{+}$homeostasis include plasma membrane (SOS1) and vacuolar $\mathrm{Na}^{+} / \mathrm{H}^{+}$antiporters (e.g., NHX1), and the plasma membrane uniporter HKT1 (Zhu 2003). Loss-of-function mutations in AtHKT1 render plants $\mathrm{Na}^{+}$hypersensitive and disturb the distribution of $\mathrm{Na}^{+}$between roots and shoots.

Ouziad et al. (2006) analyzed the expression of two $\mathrm{Na}^{+} / \mathrm{H}^{+}$ antiporter genes in dependence on salt and mycorrhizal colonization (Fig. 13). They observed that under the conditions employed, no significant alterations by mycorrhization were detected in the expression of LeNHXI and LeNHX2, the latter of which had previously been shown to be also a $\mathrm{K}^{+} / \mathrm{H}^{+}$antiporter (Venema et al. 2003).

\subsubsection{Cyclic nucleotide-gated channels}

Ion influx is central to signal transduction, and one of the potential pathways for the uptake of these ions is via cyclic nucleotide-gated ion channels (CNGCs) (Talke et al. 2003).
Cyclic nucleotides monophosphate (NMP) have only recently been accepted as important secondary messengers in plants and they have been suggested to be involved in plant responses to both biotic and abiotic stresses. It is well known that salt and osmotic stress cause rapid increases in cGMP levels in Arabidopsis thaliana (Donaldson et al. 2004), and these studies are consistent with findings that cAMP and cGMP improve tolerance to salt stress (Maathuis and Sanders 2001). Interestingly, improved salt tolerance correlated with cNMP-dependent decrease of channel open probability and reduced influx of $\mathrm{Na}^{+}$(Maathuis and Sanders 2001; Rubio et al. 2003). Furthermore, cNMPs participate in various developmental processes in addition to photomorphogenesis.

Members of the CNGC family belong to the group of nonselective cation channels and enable the uptake of $\mathrm{Na}^{+}, \mathrm{K}^{+}$, and $\mathrm{Ca}^{2+}$ (Kaplan et al. 2007). They were first identified in vertebrate visual and olfactory signal transduction cascades (Zagotta and Siegelbaum 1996; Craven and Zagotta 2006), however, much less is known about them in plants. CNGCs are composed of six transmembrane domains and a pore region between the fifth and sixth domains (Fig. 14). The fourth transmembrane domain has similarities to the Shakertype voltage sensor (Köhler et al. 1999; Rehmann et al. 2007). The N-terminal domain extends into the cytosol and is believed to bind calmodulin (CaM), while the C-terminal domain binds cNMPs. Plants, on the other hand, possess a slightly different structure where both the $\mathrm{CaM}$ and cyclic nucleotide binding domains occur in the cytosolic $\mathrm{C}$-terminus in overlapping regions.

The Arabidopsis CNGC gene family comprises 20 members (Mäser et al. 2001). Studies on some Arabidopsis CNGCs have so far revealed their ability to transport cations that play a role in mediating various environmental stresses

(A) Root

(B) Leaf

\begin{tabular}{|c|c|c|c|c|c|c|c|c|}
\hline & \multicolumn{2}{|c|}{ control } & \multicolumn{2}{|c|}{$\mathrm{NaCl}$} & \multicolumn{2}{|c|}{ control } & \multicolumn{2}{|c|}{$\mathrm{NaCl}$} \\
\hline & NM & $\mathbf{M}$ & NM & $\mathbf{M}$ & NM & M & $\mathbf{N M}$ & $\mathbf{M}$ \\
\hline & 1.2 & 1 & 1.2 & 1 & 1.3 & 1 & 1 & 1.1 \\
\hline LeNHXI & ntale & enes & $=0$ & $-m$ & $=0$ & & 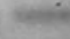 & nim. \\
\hline \multicolumn{9}{|l|}{ 18S-rRNA } \\
\hline & 1.3 & 1 & 1.4 & 1.3 & 1.2 & 1 & 1.1 & 1.1 \\
\hline LeNHX2 & $=$ & - & 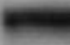 & . & $=$ & $=$ & $F$ & 10 \\
\hline $18 \mathrm{~S}-\mathrm{rRNA}$ & & & & & & & & \\
\hline
\end{tabular}

Fig. 13 Northern hybridizations using total mRNA and the different digoxigenin-labelled riboprobes for two L. esculentum $\mathrm{Na}^{+} / \mathrm{H}^{+}$ antiporters. Lowest signal intensity of one lane was arbitrary set to 1 to allow a comparison of the signal strengths within one blot (bloc of four lanes) for each gene expressed. Signal strengths were adjusted to the amount of $18 \mathrm{~S}$ rRNA blotted onto each lane. a Root and $\mathbf{b}$ leaf. $M$ mycorrhizal plants, $N M$ non-mycorrhizal plants, control plants not stressed with $\mathrm{NaCl}$. Adapted from Ouziad et al. (2006) with kind permission from Elsevier 


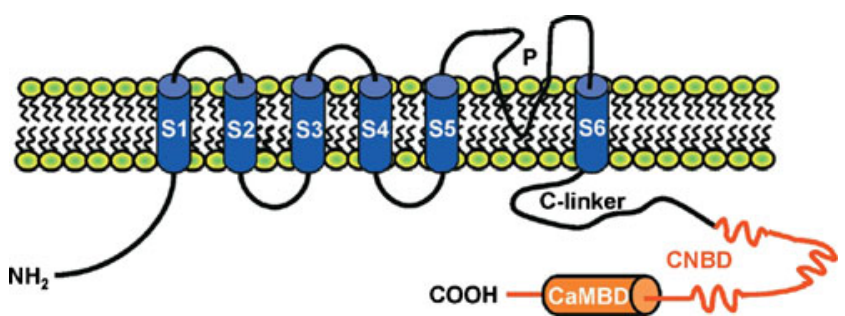

Fig. 14 Structure of plant cyclic-nucleotide-gated ion channels (CNGC). CNGCs are composed of six transmembrane domains (S) and a pore region $(\mathrm{P})$ between the fifth and sixth domains. The cytosolic C-terminus has a C-linker followed by the cyclic nucleotide binding domain (CNBD) with an overlapping calmodulin bindig domain (CAMBD)

including salt stress, plant defense responses and development (Clough et al. 2000; Balagué et al. 2003; Chan et al. 2003; Gobert et al. 2006; Ma et al. 2006; Yoshioka et al. 2006; Borsics et al. 2007), summarized in Table 4.

Recently, Kugler et al. (2009), have reported that both $A t C N G C 19$ and $A t C N G C 20$ were upregulated in the shoot in response to elevated $\mathrm{NaCl}$ but not to mannitol concentrations. While in the root, $C N G C 19$ did not respond to changes in the salt concentration, in the shoot it was strongly upregulated. Salt induction of $C N G C 20$ was also observed in the shoot. No differences in $\mathrm{K}$ and $\mathrm{Na}$ contents of the shoots were measured in homozygous T-DNA insertion lines for $C N G C 19$ and $C N G C 20$, respectively, which developed a growth phenotype in the presence of up to $75 \mathrm{mM} \mathrm{NaCl}$ similar to that of the wild type. All these results suggest that both channels are involved in the salinity response of different cell types in the shoot. Hence, $C N G C 19$ and $C N G C 20$ could assist the plant to cope with toxic effects caused by salt stress, probably by contributing to a reallocation of sodium within the plant.

In spite of the importance of CNGCs in plant cation homeostasis, there are no investigations about CNGCs in mycorrhizal plants. Thus, this is another key to understanding CNGC function in plants subjected to salt stress in future studies. Indeed, it seems apparent that CNGCs play important roles for plant survival and adaptation by mediating multiple stress responses and developmental pathways.

\section{Perspectives for future studies}

The complexion of the Arabidopsis genome-sequencing project revealed a large family of CNGCs composed of 20 members with overall sequence similarities ranging between $55 \%$ and $83 \%$ (Mäser et al. 2001). While mammalian genomes (in which they were discovered) have so far been found to contain six CNGC-encoding genes, the large number and diversity of their plant counterparts suggests important and perhaps very specialized physiological roles of CNGCs in plants. In the case of $\mathrm{Na}^{+} / \mathrm{H}^{+}$ antiporters, six fully sequenced members and at least 40 potential other candidates have been recognized (Xia et al. 2002). Although numerous studies have shown that overexpression of some $\mathrm{Na}^{+} / \mathrm{H}^{+}$antiporters results in more salt tolerant plants (Gaxiola et al. 1999; Sottosanto et al. 2004) and it is known that some CNGCs such as AtCNGC19 and
Table 4 Ion selectivity and physiological roles identified in plant cyclic-nucleotide-gated channels

\begin{tabular}{|c|c|c|}
\hline Gene & Ion selectivity & Suggested physiological role \\
\hline \multicolumn{3}{|c|}{ Arabidopsis thaliana } \\
\hline AtCNGC1 & $\mathrm{K}^{+}, \mathrm{Na}^{+}, \mathrm{Ca}^{2+}, \mathrm{Pb}^{2+}$ & $\begin{array}{l}\text { Cation uptake from soil } \\
\text { Heavy metal uptake }\end{array}$ \\
\hline AtCNGC2 & $\mathrm{K}^{+}, \mathrm{Ca}^{2+}, \mathrm{Li}^{+} \mathrm{Cs}^{+}, \mathrm{Rb}^{2+}$ & $\begin{array}{l}\text { Developmental cell death and senescence } \\
\text { Growth and development } \\
\text { Pathogen resistance }\end{array}$ \\
\hline AtCNGC3 & $\mathrm{K}^{+}, \mathrm{Na}^{+}$ & $\begin{array}{l}\text { Distribute and translocate ion from xylem } \\
\text { Translocate } \mathrm{Na}^{+} \text {within embryo }\end{array}$ \\
\hline AtCNGC4 & $\mathrm{K}^{+}, \mathrm{Na}^{+}$ & Pathogen resistance \\
\hline AtCNGC10 & $\mathrm{K}^{+}$ & Light modulated development \\
\hline AtCNGC11 & $\mathrm{K}^{+}, \mathrm{Ca}^{2+}$ & Pathogen resistance \\
\hline AtCNGC12 & $\mathrm{K}^{+}, \mathrm{Ca}^{2+}$ & Pathogen resistance \\
\hline AtCNGC18 & $\mathrm{Ca}^{2+}$ & Polarized pollen tube growth \\
\hline \multicolumn{3}{|c|}{ Nicotiana tabacum } \\
\hline $\mathrm{NtCPB} 4$ & $\mathrm{~Pb}^{2+}$ & Heavy metal uptake \\
\hline \multicolumn{3}{|c|}{ Hordeum vulgare } \\
\hline HvCBT1 & Unknown & Ion transport in aleurona \\
\hline NEC1 & Unknown & Pathogen resistance \\
\hline
\end{tabular}


AtCNGC20 could assist the plant to cope with toxic effects caused by salt stress (Kugler et al. 2009), much remains unknown on this topic.

In relation to arbuscular mycorrhizal symbiosis, it is interesting to note that there are no studies regarding CNGCs and only a few investigations have been carried out with cation:proton antiporters (Ouziad et al. 2006). Thus, we propose that investigating the participation of cation proton antiporters and cyclic nucleotide-gated channels on arbuscular mycorrhizal symbiosis under salinity is a promising field that should shed further light on new mechanisms involved in the enhanced tolerance of AM plants to salt stress. Indeed, these studies would allow understanding if the AM symbiosis affects sodium uptake, distribution, and compartimentation within the plant cell. Overall, these investigations should open new research lines aimed at obtaining maximum benefit from the AM symbiosis under salinity or other osmotic stress conditions.

\section{References}

Ábrahám E, Rigó G, Székely G, Nagy R, Koncz C, Szabados L (2003) Light-dependent induction of proline biosynthesis by abscisic acid and salt stress is inhibited by brassinosteroid in Arabidopsis. Plant Mol Biol 51:363-372

Adiku SGK, Renger M, Wessolek G, Facklam M, Hecht-Bucholtz C (2001) Simulation of the dry matter production and seed yield of common beans under varying soil water and salinity conditions. Agr Water Manage 47:55-68

Al-Garni SMS (2006) Increased heavy metal tolerance of cowpea plants by dual inoculation of an arbuscular mycorrhizal fungi and nitrogen-fixer Rhizobium bacterium. Afr J Biotechnol 5:133-142

Alguacil MM, Hernández JA, Caravaca F, Portillo B, Roldán A (2003) Antioxidant enzyme activities in shoots from three mycorrhizal shrub species afforested in a degraded semi-arid soil. Physiol Plant 118:562-570

Aliasgharzadeh N, Rastin NS, Towfighi H, Alizadeh A (2001) Occurrence of arbuscular mycorrhizal fungi in saline soils of the Tabriz Plain of Iran in relation to some physical and chemical properties of soil. Mycorrhiza 11:119-122

Al-Karaki GN (2000) Growth of mycorrhizal tomato and mineral acquisition under salt stress. Mycorrhiza 10:51-54

Al-Karaki GN (2006) Nursery inoculation of tomato with arbuscular mycorrhizal fungi and subsequent performance under irrigation with saline water. Sci Hortic 109:1-7. doi:10.1016/j.scienta.2006.02.019

Al-Karaki GN, Clark RB (1998) Growth, mineral acquisition, and water use by mycorrhizal wheat grown under water stress. J Plant Nutr 21:263-276

Al-Karaki GN, Hammad R, Rusan M (2001) Response of two tomato cultivars differing in salt tolerance to inoculation with mycorrhizal fungi under salt stress. Mycorrhiza 11:43-47

Andrade G, Azcón R, Bethlenfalvay GJ (1995) A rhizobacterium modifies plant and soil responses to the mycorrhizal fungus Glomus mosseae. Appl Soil Ecol 2:195-202

Andrade G, Mihara KL, Linderman RG, Bethlenfalvay GJ (1998) Soil aggregation status and rhizobacteria in the mycorrhizosphere. Plant Soil 202:89-96
Aroca R, Ferrante A, Vernieri P, Chrispeels MJ (2006) Drought, abscisic acid and transpiration rate effects on the regulation of PIP aquaporin gene expression and abundance in Phaseolus vulgaris plants. Ann Bot 98:1301-1310. doi:10.1093/aob/mcl219

Aroca R, Porcel R, Ruiz-Lozano JM (2007) How does arbuscular mycorrhizal symbiosis regulate root hydraulic properties and plasma membrane aquaporins in Phaseolus vulgaris under drought, cold or salinity stresses? New Phytol 173:808-816. doi:10.1111/j.1469-8137.2006.01961.x

Augé RM (2000) Stomatal behaviour of arbuscular mycorrhizal plants. In: Kapulnik Y, Douds D (eds) Arbuscular mycorrhizas: physiology and function. Kluwer Academic Publishers, Dordrecht, pp 201-237

Babu RC, Zhang JX, Blum A, Ho THD, Wu R, Nguyen HT (2004) HVA1, a LEA gene from barley confers dehydration tolerance in transgenic rice (Oryza sativa L.) via cell membrane protection. Plant Sci 166:855-862. doi:10.1016/j.plantsci.2003.11.023

Balagué C, Lin BQ, Alcon C, Flottes G, Malmström S, Köhler C, Neuhaus G, Pelletier G, Gaymard F, Roby D (2003) HLM1, an essential signaling component in the hypersensitive response, is a member of the cyclic nucleotide-gated channel ion channel family. Plant Cell 15:365-379. doi:10.1105/tpc.006999

Barea JM, Azcón R, Azcón-Aguilar C (2005) Interactions between mycorrhizal fungi and bacteria to improve plant nutrient cycling and soil structure. In: Buscot F, Varma A (eds) Microorganisms in soils: roles in genesis and functions. Springer, Berlin, pp 195-212

Barea JM, Toro M, Orozco MO, Campos E, Azcón R (2002) The application of isotopic ${ }^{32} \mathrm{P}$ and ${ }^{15} \mathrm{~N}$-dilution techniques to evaluate the interactive effect of phosphate-solubilizing rhizobacteria, mycorrhizal fungi and Rhizobium to improve the agronomic efficiency of rock phosphate for legume crops. Nutr Cycl Agroecosyst 63:35-42

Benavides MP, Marconi PL, Gallego SM, Comba ME, Tomaro ML (2000) Relationship between antioxidant defence systems and salt tolerance in Solanum tuberosum. Austr J Plant Physiol 27:273-278

Bethlenfalvay GJ, Cantrell IC, Mihara KL, Schreiner RP (1999) Relationships between soil aggregation and mycorrhizae as influenced by soil biota and nitrogen nutrition. Biol Fertil Soils 28:356-363

Bethlenfalvay GJ, Schüepp H (1994) Arbuscular mycorrhizas and agrosystem stability. In: Gianinazzi S, Schüepp H (eds) Impact of arbuscular mycorrhizas on sustainable agriculture and natural ecosystems. Birkhäuser, Basel, Switzerland, pp 117-131

Bohnert HJ, Jensen RG (1996) Strategies for engineering water-stress tolerance in plants. Trends Biotechnol 14:89-97

Bolandnazar S, Aliasgarzadeh N, Neishabury MR, Chaparzadeh N (2007) Mycorrhizal colonization improves onion (Allium cepa L.) yield and water use efficiency under water deficit condition. Sci Hortic 114:11-15. doi:10.1016/j.scienta.2007.05.012

Borsics T, Webb D, Andeme-Ondzighi C, Staehelin LA, Christopher DA (2007) The cyclic nucleotide-gated calmodulin-binding channel AtCNGC10 localizes to the plasma membrane and influences numerous growth responses and starch accumulation in Arabidopsis thaliana. Planta 225:563-573. doi:10.1007/ s00425-006-0372-3

Bowler C, Van Montagu MV, Inzé D (1992) Superoxide dismutase and stress tolerance. Ann Rev Plant Physiol Plant Mol Biol 43:83-116

Breuninger M, Requena N (2004) Recognition events in AM symbiosis: analysis of fungal gene expression at the early appressorium stage. Fungal Genet Biol 41:794-804. doi:10.1016/ j.fgb.2004.04.002

Brundett MC, Abbott LK (1991) Roots of jarrah forest plants. 1. Mycorrhizal associations of shrubs and herbaceous plants. Aust $\mathrm{J}$ Bot 39:445-457 
Cantrell IC, Linderman RG (2001) Preinoculation of lettuce and onion with VA mycorrhizal fungi reduces deleterious effects of soil salinity. Plant Soil 233:269-281

Carvalho LM, Cacador I, Martins-Loução MA (2001) Temporal and spatial variation of arbuscular mycorrhizas in salt marsh plants of the Tagus estuary (Portugal). Mycorrhiza 11:303-309

Chan CWM, Schorrak LM, Smith RK, Bent AF, Sussman MR (2003) A cyclic nucleotide-gated ion channel, $\mathrm{CNGC} 2$, is crucial for plant development and adaptation to calcium stress. Plant Physiol 132:728-731. doi:10.1104/pp.102.019216

Chaumont F, Barrieu F, Wojcik E, Chrispeels MJ, Jung R (2001) Aquaporins constitute a large and highly divergent protein family in maize. Plant Physiol 125:1206-1215

Chinnusamy V, Jagendorf A, Zhu JK (2005) Understanding and improving salt tolerance in plants. Crop Sci 45:437-448

Close T (1996) Dehydrins: emergence of a biochemical role of a family of plant dehydration proteins. Physiol Plant 97:795-803

Clough SJ, Fengler KA, Yu IC, Lippok B, Smith RK, Bent AF (2000) The Arabidopsis dnd1 "defense, no death" gene encodes a mutated cyclic nucleotide-gated ion channel. Proc Natl Acad Sci USA 97:9323-9328

Compant S, van der Heijden MG, Sessitsch A (2010) Climate change effects on beneficial plant-microorganism interactions. FEMS Microbiol Ecol 73:197-214. doi:10.1111/j.1574-6941.2010.00900.x

Craven KB, Zagotta WN (2006) CNG and HCN channels: two peas, one pod. Ann Rev Physiol 68:375-401. doi:10.1146/annurev. physiol.68.040104.134728

Dalton DA (1995) Antioxidant defenses of plants and fungi. In: Ahmad S (ed) Oxidative stress and antioxidant defenses in biology. Chapman and Hall, New York, pp 298-355

Dasgan HY, Aktas H, Abak K, Cakmak I (2002) Determination of screening techniques to salinity tolerance in tomatoes and investigation of genotype responses. Plant Sci 163:695-703

Donaldson L, Ludidi N, Knight MR, Gehring C, Denby K (2004) Salt and osmotic stress cause rapid increases in Arabidopsis thaliana cGMP levels. FEBS Lett 569:317-320. doi:10.1016/j. febslet.2004.06.016

Duan XG, Neuman DS, Reiber JM, Green CD, Saxton AM, Augé RM (1996) Mycorrhizal influence on hydraulic and hormonal factors implicated in the control of stomatal conductance during drought. J Exp Bot 47:1541-1550

Duke ER, Johnson CR, Koch KE (1986) Accumulation of phosphorus, dry matter and betaine during Nacl stress of split-root Citrus seedlings colonized with vesicular arbuscular mycorrhizal fungi on zero, one or two halves. New Phytol 104:583-590

Estrada-Luna AA, Davies FT (2003) Arbuscular mycorrhizal fungi influence water relations, gas exchange, abscisic acid and growth of micropropagated chile ancho pepper (Capsicum annuum) plantlets during acclimatization and postacclimatization. J Plant Physiol 160:1073-1083

Evelin H, Kapoor R, Giri B (2009) Arbuscular mycorrhizal fungi in alleviation of salt stress: a review. Ann Bot 104:1263-1280. doi:10.1093/aob/mcp251

Feng G, Zhang FS, Li XL, Tian CY, Tang C, Rengel Z (2002) Improved tolerance of maize plants to salt stress by arbuscular mycorrhiza is related to higher accumulation of soluble sugars in roots. Mycorrhiza 12:185-190. doi:10.1007/s00572-002-0170-0

Flowers TJ, Colmer TD (2008) Salinity tolerance in halophytes. New Phytol 179:945-963. doi:10.1111/j.1469-8137.2008.02531.x

Fukuda A, Nakamura A, Tanaka Y (1999) Molecular cloning and expression of the $\mathrm{Na}+\mathrm{H}+$ exchanger gene in Oryza sativa. Biochim Biophys Acta Gene Struct Expr 1446:149-155

Gamalero E, Lingua G, Berta G, Glick BR (2009) Beneficial role of plant growth promoting bacteria and arbuscular mycorrhizal fungi on plant responses to heavy metal stress. Can J Microbiol 55:501-514. doi:10.1139/W09-010
Garg N, Manchanda G (2008) Effect of arbuscular mycorrhizal inoculation of salt-induced nodule senescence in Cajanus cajan (pigeonpea). J Plant Growth Regul 27:115-124. doi:10.1007/ s00344-007-9038-z

Gaxiola RA, Rao R, Sherman A, Grisafi P, Alper SL, Fink GR (1999) The Arabidopsis thaliana proton transporters, AtNhx1 and Avp1, can function in cation detoxification in yeast. Proc Nat Acad Sci USA 96:1480-1485

George E (2000) Nutrient uptake. In: Douds KY, Jr DD (eds) Arbuscular mycorrhizas: physiology and function. Kluwer Academic, Dordrecht, pp 307-343

Giovannetti M, Azzolini D, Citernesi AS (1999) Anastomosis formation and nuclear and protoplasmic exchange in arbuscular mycorrhizal fungi. Appl Environ Microbiol 65:55715575

Giovannetti M, Sbrana C, Logi C (1994) Early processes involved in host recognition by arbuscular mycorrhizal fungi. New Phytol 127:703-709

Giri B, Kapoor R, Mukerji KG (2003) Influence of arbuscular mycorrhizal fungi and salinity on growth, biomass, and mineral nutrition of Acacia auriculiformis. Biol Fertil Soils 38:170-175. doi:10.1007/s00374-003-0636-Z

Giri B, Kapoor R, Mukerji KG (2007) Improved tolerance of Acacia nilotica to salt stress by arbuscular mycorrhiza, Glomus fasciculatum may be partly related to elevated $\mathrm{K} / \mathrm{Na}$ ratios in root and shoot tissues. Microb Ecol 54:753-760. doi:10.1007/s00248-007-9239-9

Giri B, Mukerji KG (2004) Mycorrhizal inoculant alleviates salt stress in Sesbania aegyptiaca and Sesbania grandiflora under field conditions: evidence for reduced sodium and improved magnesium uptake. Mycorrhiza 14:307-312. doi:10.1007/s00572-003-0274-1

Gobert A, Park G, Amtmann A, Sanders D, Maathuis FJM (2006) Arabidopsis thaliana cyclic nucleotide-gated channel 3 forms a non-selective ion transporter involved in germination and cation transport. J Exp Bot 57:791-800. doi:10.1093/jxb/erj064

Goicoechea N, Antolin MC, Sánchez-Díaz M (1997) Gas exchange is related to the hormone balance in mycorrhizal or nitrogen-fixing alfalfa subjected to drought. Physiol Plant 100:989-997

Gorham J (1995) Betaines in higher plants-biosynthesis and role in stress metabolism. In: Wallsgrove RM (ed) Amino acids and their derivatives in higher plants. Cambridge University Press, Cambridge, pp 173-203

Gossett DR, Millhollon EP, Lucas MC (1994) Antioxidant response to Nacl stress in salt-tolerant and salt-sensitive cultivars of cotton. Crop Sci 34:706-714

Grime JP, Mackey JML, Hillier SH, Read DJ (1987) Floristic diversity in a model system using experimental microcosms. Nature 328:420-422

Gutteridge JM, Halliwell B (1989) Iron toxicity and oxygen radicals. Baillières Clin Haematol 2:195-256

Hajiboland R, Aliasgharzadeh N, Laiegh SF, Poschenrieder C (2010) Colonization with arbuscular mycorrhizal fungi improves salinity tolerance of tomato (Solanum lycopersicum L.) plants. Plant Soil 331:313-327

Hajiboland R, Joudmand A (2009) The K/Na replacement and function of antioxidant defence system in sugar beet (Beta vulgaris L.) cultivars. Acta Agr Scand Section B-Soil and Plant Sci 59:246-259. doi:10.1080/09064710802029544

Hajiboland R, Joudmand A, Fotouhi K (2009) Mild salinity improves sugar beet (Beta vulgaris L.) quality. Acta Agr Scand Section B-Soil and Plant Sci 59:295-305. doi:10.1080/09064710802154714

Hanway JJ, Heidel H (1952) Soil analysis methods as used in Iowa State College soil testing laboratory. Iowa Agri news 57:1-31

He XH, Nara K (2007) Element biofortification: can mycorrhizas potentially offer a more effective and sustainable pathway to curb human malnutrition? Trends Plant Sci 12:331-333. doi:10.1016/ j.tplants.2007.06.008 
Heinen RB, Ye Q, Chaumont F (2009) Role of aquaporins in leaf physiology. J Exp Bot 60:2971-2985. doi:10.1093/jxb/erp171

Hildebrandt U, Regvar M, Bothe H (2007) Arbuscular mycorrhiza and heavy metal tolerance. Phytochemistry 68:139-146. doi:10.1016/ j.phytochem.2006.09.023

Hirrel MC, Gerdemann JW (1980) Improved growth of onion and bell pepper in saline soils by two vesicular-arbuscular mycorrhizal fungi. Soil Sci Soc Amer J 44:654-655

Hu C-A, Delauney A, Verma Desh Pal S (1992) A bifunctional enzyme (pyrroline-5-carboxylate syntethase) catalyzes the first two steps in proline biosynthesis in plants. Proc Natl Acad Sci USA 89:9354 9358

Imai R, Chang L, Ohta A, Bray EA, Takagi M (1996) A lea-class gene of tomato confers salt and freezing tolerance when expressed in Saccharomyces cerevisiae. Gene 170:243-248

Ishikawa F, Suga S, Uemura T, Sato MH, Maeshima M (2005) Novel type aquaporin SIPs are mainly localized to the ER membrane and show cell-specific expression in Arabidopsis thaliana. FEBS Lett 579:5814-5820. doi:10.1016/j.febslet.2005.09.076

Jahromi F, Aroca R, Porcel R, Ruiz-Lozano JM (2008) Influence of salinity on the in vitro development of Glomus intraradices and on the in vivo physiological and molecular responses of mycorrhizal lettuce plants. Microb Ecol 55:45-53. doi:10.1007/ s00248-007-9249-7

Jakob B, Heber U (1996) Photoproduction and detoxification of hydroxyl radicals in chloroplasts and leaves and relation to photoinactivation of photosystems I and II. Plant Cell Physiol 37:629-635

Jeffries P, Barea JM (2001) Arbuscular mycorrhiza: a key component of sustainable plant-soil ecosystems. In: Hock B (ed) The Mycota: fungal associations, Vol. IX. Springer, Berlin, pp 95-113

Jiménez A, Hernández JA, del Río LA, Sevilla F (1997) Evidence for the presence of the ascorbate-glutathione cycle in mitochondria and peroxisomes of pea leaves. Plant Physiol 114:275-284

Jindal V, Atwal A, Sekhon BS, Singh R (1993) Effect of vesiculararbuscular mycorrhizae on metabolism of moong plants under Nacl salinity. Plant Physiol Biochem 31:475-481

Johanson U, Karlsson M, Johansson I, Gustavsson S, Sjövall S, Fraysse L, Weig AR, Kjellbom P (2001) The complete set of genes encoding major intrinsic proteins in Arabidopsis provides a framework for a new nomenclature for major intrinsic proteins in plants. Plant Physiol 126:1358-1369

Juniper S, Abbott LK (2006) Soil salinity delays germination and limits growth of hyphae from propagules of arbuscular mycorrhizal fungi. Mycorrhiza 16:371-379. doi:10.1007/s00572-006-0046-9

Juniper S, Abbott LK (1993) Vesicular-arbuscular mycorrhizas and soil salinity. Mycorrhiza 4:45-57

Kaplan B, Sherman T, Fromm H (2007) Cyclic nucleotide-gated channels in plants. FEBS Lett 581:2237-2246. doi:10.1016/j. febslet.2007.02.017

Khalvati MA, Hu Y, Mozafar A, Schmidhalter U (2005) Quantification of water uptake by arbuscular mycorrhizal hyphae and its significance for leaf growth, water relations, and gas exchange of barley subjected to drought stress. Plant Biol 7:706-712. doi:10.1055/s-2005-872893

Kishor PB, Hong Z, Miao G-H (1995) Overexpression of pyrroline-5carboxylate synthetase increases proline production and confers osmotolerance in transgenic plants. Plant Physiol 108:1387-1394

Kilironomos JN, Moutoglis P, Kendrick B, Widden P (1993) A comparison of spatial heterogeneity of vesicular-arbuscular mycorrhizal fungi in two maple forest soils. Can J Bot 71:1472-1480

Koag MC, Fenton RD, Wilkens S, Close TJ (2003) The binding of maize DHN1 to lipid vesicles. Gain of structure and lipid specificity. Plant Physiol 131:309-316. doi:10.1104/pp.011171

Köhler C, Merkle T, Neuhaus G (1999) Characterisation of a novel gene family of putative cyclic nucleotide- and calmodulin-regulated ion channels in Arabidopsis thaliana. Plant J 18:97-104
Koske RE (1981) Multiple germination by spores of Gigaspora gigantea. Trans Brit Mycol Soc 76:328-330

Krajinski F, Biela A, Schubert D, Gianinazzi-Pearson V, Kaldenhoff R, Franken P (2000) Arbuscular mycorrhiza development regulates the mRNA abundance of Mtaqpl encoding a mercury-insensitive aquaporin of Medicago truncatula. Planta 211(1):85-90

Kruse E., Uehlein N., Kaldenhoff R. (2006) The aquaporins. Genome Biol. 7. doi:10.1186/gb-2006-7-2-206.

Kugler A, Köhler B, Palme K, Wolff P (2009) Salt-dependent regulation of a CNG channel subfamily in Arabidopsis. BMC Plant Biol 9:140. doi:10.1186/1471-2229-9-140

Linderman RG (2000) Effects of mycorrhizas on plant tolerance to diseases. In: Kapulnik Y, Douds DD Jr (eds) Arbuscular mycorrhizas: physiology and function. Kluwer Academic Publishers, Dordrecht, The Netherlands, pp 345-365

Logi C, Sbrana C, Giovannetti M (1998) Cellular events involved in survival of individual arbuscular mycorrhizal symbionts growing in the absence of the host. Appl Environ Microbiol 64:3473-3479

Ludwig-Muller J (2000) Indole-3-butyric acid in plant growth and development. Plant Growth Regul 32:219-230

Luu DT, Maurel C (2005) Aquaporins in a challenging environment: molecular gears for adjusting plant water status. Plant Cell Environ 28:85-96

Ma W, Ali R, Berkowitz GA (2006) Characterization of plant phenotypes associated with loss-of-function of AtCNGC1, a plant cyclic nucleotide gated cation channel. Plant Physiol Biochem 44:494-505. doi:10.1016/j.plaphy.2006.08.007

Maathuis FJM, Sanders D (2001) Sodium uptake in Arabidopsis roots is regulated by cyclic nucleotides. Plant Physiol 127:1617-1625

Mahajan S, Tuteja N (2005) Cold, salinity and drought stresses: an overview. Arch Biochem Biophys 444:139-158. doi:10.1016/j. abb.2005.10.018

Marjanovic Z, Uehlein N, Kaldenhoff R, Zwiazek JJ, Wei M, Hampp R, Nehls U (2005) Aquaporins in poplar: what a difference a symbiont makes! Planta 222:258-268. doi:10.1007/ s00425-005-1539-z

Marschner H, Kuiper PJC, Kylin A (1981) Genotypic differences in the response of sugar-beet plants to replacement of potassium by sodium. Physiol Plant 51:239-244

Marschner H., (1995) (Eds.) Mineral nutrition of higher plants, Second edition, Academic Press, London, UK.

Marulanda A, Azcón R, Ruiz-Lozano JM (2003) Contribution of six arbuscular mycorrhizal fungal isolates to water uptake by Lactuca sativa plants under drought stress. Physiol Plant 119:526-533

Marulanda A, Porcel R, Barea JM, Azcón R (2007) Drought tolerance and antioxidant activities in lavender plants colonized by native drought-tolerant or drought-sensitive Glomus species. Microb Ecol 54:543-552. doi:10.1007/s00248-007-9237-y

Mäser P, Thomine S, Schroeder JI, Ward JM, Hirschi K, Sze H, Talke IN, Amtmann A, Maathuis FJM, Sanders D, Harper JF, Tchieu J, Gribskov M, Persans MW, Salt DE, Kim SA, Guerinot ML (2001) Phylogenetic relationships within cation transporter families of Arabidopsis. Plant Physiol 126:1646-1667

Maurel C, Santoni V, Luu DT, Wudick MM, Verdoucq L (2009) The cellular dynamics of plant aquaporin expression and functions. Curr Opin Plant Biol 12:690-698. doi:10.1016/j. pbi.2009.09.002

Menconi M, Sgherri CLM, Pinzino C, Navariizzo F (1995) Activated oxygen production and detoxification in wheat plants subjected to a water deficit program. J Exp Bot 46:1123-1130

Miller RM, Jastrow JD (2000) Mycorrhizal fungi influence soil structure. In: Kapulnik Y, Douds DD Jr (eds) Arbuscular mycorrhizas: physiology and functions. Kluwer Academic Publishers, Dordrecht, The Netherlands, pp 3-18 
Miransari M (2010) Contribution of arbuscular mycorrhizal symbiosis to plant growth under different types of soil stress. Plant Biol 1:563-569. doi:10.1111/j.1438-8677.2009.00308.x

Mohammad MJ, Malkawi HI, Shibli R (2003) Effects of arbuscular mycorrhizal fungi and phosphorus fertilization on growth and nutrient uptake of barley grown on soils with different levels of salts. J Plant Nutr 26:125-137. doi:10.1081/PLN-120016500

Mukerji KG, Ciancio A (2007) Mycorrhizae in the integrated pest and disease. In: Ciancio A, Mukerji KG (eds) Management general concepts in mycosphere integrated pest and disease management. Springer, The Netherlands, pp 245-266

Murkute AA, Sharma S, Singh SK (2006) Studies on salt stress tolerance of citrus rootstock genotypes with arbuscular mycorrhizal fungi. Hortic Sci 33:70-76

Noctor G, Foyer C (1998) Ascorbate and glutathione: keeping active oxygen under control. Ann Rev Plant Physiol Plant Mol Biol 49:249-279

Núñez M, Mazzafera P, Mazorra LM, Siqueira WJ, Zullo MAT (2003) Influence of a brassinosteroid analogue on antioxidant enzymes in rice grown in culture medium with $\mathrm{NaCl}$. Biol Plant 47:67-70

Ojala JC, Jarrell WM, Menge JA, Johnson ELV (1983) Influence of mycorrhizal fungi on the mineral nutrition and yield of onion in saline soil. Agron J 75:255-259

Ouziad F, Wilde P, Schmelzer E, Hildebrandt U, Bothe H (2006) Analysis of expression of aquaporins and $\mathrm{Na}^{+} / \mathrm{H}^{+}$transporters in tomato colonized by arbuscular mycorrhizal fungi and affected by salt stress. Environ Exp Bot 57:177-186. doi:10.1016/j. envexpbot.2005.05.011

Pearson JN, Schweiger P (1993) Scutellospora calospora (Nicol and Gerd) Walker and Sanders associated with subterranean cloverdynamics of colonization, sporulation and soluble carbohydrates. New Phytol 124:215-219

Pitman M, Läuchli A (2002) Global impact of salinity and agricultural ecosystems. In: Läuchli A, Lüttge U (eds) Salinity: environmentplants-molecules. Springer, Netherlands, pp 3-20

Pond EC, Menge JA, Jarrell WM (1984) Improved growth of tomato in salinized soil by vesicular-arbuscular mycorrhizal fungi collected from saline soils. Mycologia 76:74-84

Porcel R, Aroca R, Azcón R, Ruiz-Lozano JM (2006) PIP aquaporin gene expression in arbuscular mycorrhizal Glycine $\max$ and Lactuca sativa plants in relation to drought stress tolerance. Plant Mol Biol 60:389-404. doi:10.1007/s11103-005-4210-y

Porcel R, Azcón R, Ruiz-Lozano JM (2005) Evaluation of the role of genes encoding for dehydrin proteins (LEA D-11) during drought stress in arbuscular mycorrhizal Glycine max and Lactuca sativa plants. J Exp Bot 56:1933-1942. doi:10.1093/jxb/eri188

Porcel R, Ruiz-Lozano JM (2004) Arbuscular mycorrhizal influence on leaf water potential, solute accumulation, and oxidative stress in soybean plants subjected to drought stress. J Exp Bot 55:1743-1750. doi:10.1093/jxb/erh 188

Poss JA, Pond E, Menge JA, Jarrell WM (1985) Effect of salinity on mycorrhizal onion and tomato in soil with and without additional phosphate. Plant Soil 88:307-319

Pozo MJ, Azcón C (2007) Unravelling mycorrhiza-induced resistance. Curr Opin Plant Biol 10:393-398. doi:10.1016/j. pbi.2007.05.004

Querejeta JI, Egerton-Warburton LM, Allen MF (2007) Hydraulic lift may buffer rhizosphere hyphae against the negative effects of severe soil drying in a California Oak savanna. Soil Biol Biochem 39:409-417. doi:10.1016/j.soilbio.2006.08.008

Rabie GH, Almadini AM (2005) Role of bioinoculants in development of salt-tolerance of Vicia faba plants under salinity stress. Afr J Bioteh 4:210-222

Ramoliya PJ, Patel HM, Pandey AN (2004) Effect of salinization of soil on growth and macro- and micro-nutrient accumulation in seedlings of Salvadora persica (Salvadoraceae). For Ecol Manag 202:181-193. doi:10.1016/j.foreco.2004.07.020

Redecker D, Morton JB, Bruns TD (2000) Ancestral lineages of arbuscular mycorrhizal fungi (Glomales). Mol Phylogenet Evol $14: 276-284$

Rehmann H, Wittinghofer A, Bos JL (2007) Capturing cyclic nucleotides in action: snapshots from crystallographic studies. Nat Rev Mol Cell Biol 8:63-73. doi:10.1038/nrm2082

Remy W, Taylor TN, Hass H, Kerp H (1994) 4-Hundred-million-year-old vesicular-arbuscular mycorrhizae. Proc Natl Acad Sci USA 91:11841-11843

Requena N, Jeffries P, Barea JM (1996) Assessment of natural mycorrhizal potential in a desertified semiarid ecosystem. Appl Environ Microbiol 62:842-847

Requena N, Pérez-Solis E, Azcón-Aguilar C, Jeffries P, Barea JM (2001) Management of indigenous plant-microbe symbioses aids restoration of desertified. Appl Environ Microbiol 67:495-498

Rosendahl CN, Rosendahl S (1991) Influence of vesicular-arbuscular mycorrhizal fungi (Glomus Spp) on the response of cucumber (Cucumis sativus L) to salt stress. Environ Exp Bot 31:313-318

Roussel H, Bruns S, Gianinazzi-Pearson V, Hahlbrock K, Franken P (1997) Induction of a membrane intrinsic protein-encoding mRNA in arbuscular mycorrhiza and elicitor-stimulated cell suspension cultures of parsley. Plant Sci 126:203-210

Rozema J, Arp W, Vandiggelen J, Vanesbroek M, Broekman R, Punte H (1986) Occurrence and ecological significance of vesicular arbuscular mycorrhiza in the salt marsh environment. Act Bot Neerlan 35:457-467

Rubio F, Flores P, Navarro JM, Martínez V (2003) Effects of $\mathrm{Ca}^{+}, \mathrm{K}^{+}$ and cGMP on $\mathrm{Na}^{+}$uptake in pepper plants. Plant Sci 165:10431049. doi:10.1016/S0168-9452(03)00297-8

Ruiz-Lozano JM (2003) Arbuscular mycorrhizal symbiosis and alleviation of osmotic stress. New perspectives for molecular studies. Mycorrhiza 13:309-317. doi:10.1007/s00572-003-0237-6

Ruiz-Lozano J.M., Aroca R. (2011) Modulation of aquaporin genes by the arbuscular mycorrhizal symbiosis in relation to osmotic stress tolerance. In: Symbiosis and Stress. Sechback J., Grube M. (Eds.). Springer, Germany (in press)

Ruiz-Lozano JM, Azcón R (1996) Superoxide dismutase activity in arbuscular mycorrhizal Lactuca sativa plants subjected to drought stress. New Phytol 134:327-333

Ruiz-Lozano JM, Azcón R, Gómez M (1996) Alleviation of salt stress by arbuscular mycorrhizal Glomus species in Lactuca sativa plants. Physiol Plant 98:767-772

Sakurai J, Ishikawa F, Yamaguchi T, Uemura M, Maeshima M (2005) Identification of 33 rice aquaporin genes and analysis of their expression and function. Plant Cell Physiol 46:15681577

Sánchez-Blanco MJ, Ferrández T, Morales MA, Morte A, Alarcón JJ (2004) Variations in water status, gas exchange, and growth in Rosmarinus officinalis plants infected with Glomus deserticola under drought conditions. J Plant Physiol 161:675-682

Sannazzaro AI, Echeverria M, Alberto EO, Ruiz OA, Menéndez AB (2007) Modulation of polyamine balance in Lotus glaber by salinity and arbuscular mycorrhiza. Plant Physiol Biochem 45:39-46. doi:10.1016/j.plaphy.2006.12.008

Santos R, Franza T, Laporte ML, Sauvage C, Touati D, Expert D (2001) Essential role of superoxide dismutase on the pathogenicity of Erwinia chrysanthemi strain 3937. Mol Plant-Microb Interact 14:758-767

Sarda X, Tousch D, Ferrare K, Cellier F, Alcon C, Dupuis JM, Casse F, Lamaze T (1999) Characterization of closely related_TIP genes encoding aquaporins which are differentially expressed in sunflower roots upon water deprivation through exposure to air. Plant Mol Biol 40:179-191 
Serrano R, Culianz-Macia FA, Moreno V (1999) Genetic engineering of salt and drought tolerance with yeast regulatory genes. Sci Hortic 78:261-269

Sharifi M, Ghorbanli M, Ebrahimzadeh H (2007) Improved growth of salinity-stressed soybean after inoculation with salt pre-treated mycorrhizal fungi. J Plant Physiol 164:1144-1151. doi:10.1016/j. jplph.2006.06.016

Sheng M, Tang M, Chen H, Yang BW, Zhang FF, Huang YH (2008) Influence of arbuscular mycorrhizae on photosynthesis and water status of maize plants under salt stress. Mycorrhiza 18:287-296. doi:10.1007/s00572-008-0180-7

Smirnoff N (1993) The role of active oxygen in the response of plants to water deficit and desiccation. New Phytol 125:27-58

Smith SE, Read DJ (eds) (1997) Mycorrhizal symbiosis. Academic Press, San Diego, USA

Smith SE, Read DJ (eds) (2008) Mycorrhizal symbiosis. Academic Press, Inc., San Diego, USA

Sottosanto JB, Gelli A, Blumwald E (2004) DNA array analyses of Arabidopsis thaliana lacking a vacuolar $\mathrm{Na}^{+} / \mathrm{H}^{+}$antiporter: impact of AtNHX1 on gene expression. Plant J 40:752-771. doi:10.1111/j.1365-313X.2004.02253.x

Talke IN, Blaudez D, Maathuis FJM, Sanders D (2003) CNGCs: prime targets of plant cyclic nucleotide signalling? Trends Plant Sci 8:286-293

Tester M, Davenport R (2003) $\mathrm{Na}^{+}$tolerance and $\mathrm{Na}^{+}$transport in higher plants. Ann Bot 91:503-527. doi:10.1093/aob/mcg058

Thomson BD, Clarkson DT, Brain P (1990) Kinetics of phosphorus uptake by the germ tubes of the vesicular arbuscular mycorrhizal fungus, Gigaspora margarita. New Phytol 116:647-653

Tian CY, Feng G, Li XL, Zhang FS (2004) Different effects of arbuscular mycorrhizal fungal isolates from saline or non-saline soil on salinity tolerance of plants. Appl Soil Ecol 26:143-148

Trappe JM (1987) Phylogenetic and ecologic aspects of mycotrophy in the angiosperms from an evolutionary standpoint. In: Safir GR (ed) Ecophysiology of VA mycorrhizal plants. CRC Press, Boca Raton, Florida, USA, pp 5-25

Tuteja N (2007) Mechanisms of high salinity tolerance in plants. Osmosensing Osmosignaling 428:419. doi:10.1016/S0076-6879 (07)28024-3

Uehlein N, Fileschi K, Eckert M, Bienert GP, Bertl A, Kaldenhoff R (2007) Arbuscular mycorrhizal symbiosis and plant aquaporin expression. Phytochemistry 68:122-129. doi:10.1016/j.phytochem.2006.09.033

Van der Heijden MGA, Klironomos JN, Ursic M, Moutoglis P, Streitwolf-Engel R, Boller T, Wiemken A, Sanders IR (1998) Mycorrhizal fungal diversity determines plant biodiversity, ecosystem variability and productivity. Nature 396:69-72

Venema K, Belver A, Marin-Manzano MC, Rodríguez-Rosales MP, Donaire JP (2003) A novel intracellular $\mathrm{K}^{+} / \mathrm{H}^{+}$antiporter related to $\mathrm{Na}^{+} / \mathrm{H}^{+}$antiporters is important for $\mathrm{K}^{+}$ion homeostasis in plants. J Biol Chem 278:22453-22459. doi:10.1074/jbc. M210794200

Wang W, Vinocur B, Shoseyov O, Altman A (2004) Role of plant heat-shock proteins and molecular chaperones in the abiotic stress response. Trends Plant Sci 9:244-252. doi:10.1016/j. tplants.2004.03.006

Wang WX, Vinocur B, Altman A (2003) Plant responses to drought, salinity and extreme temperatures: towards genetic engineering for stress tolerance. Planta 218:1-14. doi:10.1007/s00425-003-1105-5

Wild A (1988) (Ed.) Russell's soil conditions and plant Growth. $11^{\text {th }}$ edn. Harlow; Longman
Wright SF, Upadhyaya A (1998) A survey of soils for aggregate stability and glomalin, a glycoprotein produced by hyphae of arbuscular mycorrhizal fungi. Plant Soil 198:97-107

Wu QS, Xia RX (2006) Arbuscular mycorrhizal fungi influence growth, osmotic adjustment and photosynthesis of citrus under well-watered and water stress conditions. J Plant Physiol 163:417-425. doi:10.1016/j.jplph.2005.04.024

Wu QS, Xia RX, Zou YN (2006) Reactive oxygen metabolism in mycorrhizal and non-mycorrhizal citrus (Poncirus trifoliata) seedlings subjected to water stress. J Plant Physiol 163:11011110. doi:10.1016/j.jplph.2005.09.001

Wu QS, Zou YN, Xia RX, Wang MY (2007) Five Glomus species affect water relations of Citrus tangerine during drought stress. Bot Stud 48:147-154

Wudick MM, Luu DT, Maurel C (2009) A look inside: localization patterns and functions of intracellular plant aquaporins. New Phytol 184:289-302. doi:10.1111/j.1469-8137.2009.02985.x

Xia T, Apse MP, Aharon GS, Blumwald E (2002) Identification and characterization of a NaCl-inducible vacuolar $\mathrm{Na}^{+} / \mathrm{H}^{+}$antiporter in Beta vulgaris. Physiol Plant 116:206-212

Xu D, Duan X, Wang B, Hong B (1996) Expression of a late embryogenesis abundant protein gene, HVA 1 from Barley confers tolerance to water deficit and salt stress in transgenic rice. Plant Physiol 110:249-257

Yamato M, Ikeda S, Iwase K (2008) Community of arbuscular mycorrhizal fungi in a coastal vegetation on Okinawa island and effect of the isolated fungi on growth of sorghum under salt-treated conditions. Mycorrhiza 18:241-249. doi:10.1007/s00572-008-0177-2

Yano-Melo AM, Saggin OJ, Maia LC (2003) Tolerance of mycorrhized banana (Musa sp. cv. Pacovan) plantlets to saline stress. Agric Ecosyst Environ 95:343-348

Yokoi S, Quintero FJ, Cubero B, Ruiz MT, Bressan RA, Hasegawa PM, Pardo JM (2002) Differential expression and function of Arabidopsis thaliana $\mathrm{NHX} \mathrm{Na} / \mathrm{H}^{+}$antiporters in the salt stress response. Plant J 30:529-539

Yoshiba Y, Kiyosue T, Katagiri T, Ueda H, Mizoguchi T, Yamaguchishinozaki K, Wada K, Harada Y, Shinozaki K (1995) Correlation between the induction of a gene for delta (1)-pyrroline-5-carboxylate synthetase and the accumulation of proline in Arabidopsis thaliana under osmotic stress. Plant $\mathbf{J}$ 7:751-760

Yoshioka K, Moeder W, Kang HG, Kachroo P, Masmoudi K, Berkowitz G, Klessig DF (2006) The chimeric Arabidopsis cyclic nucleotide-gated ion channel11/12 activates multiple pathogen resistance responses. Plant Cell 18:747-763. doi: $10.1105 /$ tpc. 105.038786

Zagotta WN, Siegelbaum SA (1996) Structure and function of cyclic nucleotide-gated channels. Ann Rev Neurosci 19:235-263

Zhong QH, Chao XH, Zhi BZ, Zhi RZ, Huai SW (2007) Changes in antioxidative enzymes and cell membrane osmosis in tomato colonized by arbuscular mycorrhizae under $\mathrm{NaCl}$ stress. Colloids Surf B Biointerfaces 59:128-133. doi:10.1016/j.colsurfb.2007.04.023

Zhu JK (2001) Cell signalling under salt, water and cold stresses. Curr Opin Plant Biol 4:401-406

Zhu JK (2003) Regulation of ion homeostasis under salt stress. Curr Opin Plant Biol 6:441-445. doi:10.1016/S1369-5266(03)00085-2

Zuccarini P, Okurowska P (2008) Effects of mycorrhizal colonization and fertilization on growth and photosynthesis of sweet basil under salt stress. J Plant Nutr 31:497-513. doi:10.1080/ 01904160801895027 